\title{
Review of Early to Mid Ordovician orthoconic cephalopods from Iran
}

\author{
DAVID H. EVANS, MANSOUREH GHOBADI POUR \& LEONID E. POPOV
}

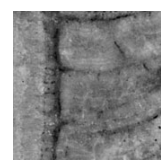

\begin{abstract}
Cephalopods from the late Tremadocian of the Eastern Alborz and the Darriwilian of the Eastern Alborz and Derenjal Mountains consist of relatively poorly preserved, low diversity assemblages of endocerids and orthoceratoids. Bactroceras sp. from the late Tremadocian of the Eastern Alborz is one the earliest occurrences of the genus; similar in age to those from the Montagne Noire, France, and consistent with other high latitude records during the Early Ordovician. Darriwilian taxa consist of an unnamed troedssonellid previously recorded from Sweden, three taxa ascribed to Virgoceras Flower, Sactorthoceras sp. and Gangshanoceras? sp. By comparison with the coeval cephalopod faunas of South China and Baltica, those described here are of very low diversity, but are common to both areas. Darriwilian cephalopod assemblages from other parts of high latitude peri-Gondwana remain poorly known, but consist of eothinoceratids, bathmoceratids, endocerids and orthoceratoids. The Iranian faunas provide a glimpse of the generic composition of part this high latitude assemblage, and indicate clear links with those of South China and Baltica. $\bullet$ Key words: Tremadocian, Darriwilian, Endocerida, Orthocerida, taxonomy, biogeography.
\end{abstract}

Evans, D.H., GHOBADI PouR, M. \& POPOV, L.E. 2013. Review of the Early to Mid Ordovician orthoconic cephalopods from Iran. Bulletin of Geosciences 88(1), 21-44 (10 figures). Czech Geological Survey, Prague. ISSN 1214-1119. Manuscript received March 20, 2012; accepted in revised form July 3, 2012; published online October 29, 2012; issued December 6, 2012.

David H. Evans (corresponding author), Natural England, $3^{\text {rd }}$ Floor, Touthill Close, City Road, Peterborough PE1 1UA, England, United Kingdom; david.evans@natural england.org.uk•Mansoureh Ghobadi Pour, Department of Geology, Faculty of Sciences, Golestan University, Gorgan, Iran and Department of Geology, National Museum of Wales, Cathays Park, Cardiff CF10 3NP, United Kingdom; mghobadipour@yahoo.co.uk • Leonid E. Popov, Department of Geology, National Museum of Wales, Cathays Park, Cardiff CF10 3NP, United Kingdom; leonid.popov@museumwales.ac.uk

Orthoconic cephalopods are an important component of the Iranian Ordovician faunas and records of their occurrence often appear in publications on the Early Palaeozoic geology and stratigraphy of various Iranian regions (e.g. Glaus 1965, Stöcklin \& Setudehnia 1991, Alavi-Naini 1993); however the only Iranian Ordovician cephalopod yet described and properly illustrated is Sactorthoceras banestanensis Evans, 2006 in Dastanpoor et al. (2006) from the Upper Ordovician Katkoyeh Formation of Banestan, Kerman Province.

The present study is based on the orthoconic cephalopod collection assembled from the Lower to Middle Ordovician sequences in Eastern Alborz and the Derenjal Mountains, north of Tabas during several fieldwork seasons between 2005 and 2010. The Derenjal Mountains are situated at the northern part of the Tabas Block within the Central Iranian terrane or microplate (Fig. 1), which according to Ramezani \& Tucker (2003) in the Early Palaeozoic can be classified as peri-Gondwanan. At present it is widely accepted that during the Ordovician, the Central Iranian terrane was an integral part of the temperate latitude Gondwana, which is well supported by biogeographic analyses (e.g. Fortey \& Cocks 2003). Palaeogeographic position of Alborz in the Ordovician is more controversial. It is often considered as a part of mainland Gondwana in the Ordovician (e.g. Fortey \& Cocks 2003, Torsvik \& Cocks 2009); however, it was most likely a separate microplate situated in temperate latitudes somewhere between the Gondwanan margin and South China (Ghobadi Pour et al. 2011c).

In Alborz the orthoconic cephalopods occur in two horizons: one is dated by associated conodonts as the uppermost Tremadocian and another one is in the middle to upper Darriwilian. Earlier, Glaus (1965) reported the occurrence of Endoceras sp. and Michelinoceras sp. in the lower part of the Lashkarak Formation, which can be dated as Darriwilian according to Ghobadi Pour et al. (2011c), but presence of these genera has not found confirmation after study of the specimens obtained from the Lashkarak Formation in Eastern Alborz. 
In Central Iran, orthoconic cephalopods are relatively common in the Middle Ordovician part of the Shirgesht Formation of the Derenjal Mountains. The studied specimens came from the same locality as the cephalopod shells illustrated by Kalantari (1981, pl. 2, figs 5-14) as Orthoceras vagans Salter, 1849, which is most probably a misidentification, and has not been confirmed by the specimens identified in a newly available material.

All cephalopod specimens described here are housed in the Department of Geology, National Museum of Wales, UK; Accession Number NMW 2012.15G.

\section{Geological and geographical setting}

\section{Eastern Alborz Region}

In the Eastern Alborz the orthoconic cephalopods were collected from two sections. The first one is the Simeh-Kuh section, which is situated at about $13 \mathrm{~km}$ north-west of the city of Damghan (Fig. 1). The second one is the Deh-Molla section, situated at about $60 \mathrm{~km}$ east of the previous section, north of Kalat-e Molla village at about $15 \mathrm{~km}$ south-west of the city of Shahrud (Fig. 1). The Lower to Middle Ordovician sequence in Simeh-Kuh was documented in a number of publications (Ghobadi Pour 2006; Ghobadi Pour et al. 2007a; Popov et al. 2008, 2009), whereas the Ordovician sequence in Deh-Molla is mainly known from publications of Ghavidel-Syooki 2006 and Ghobadi Pour et al. 2011a, 2011b). The Lower to Middle Ordovician sediments in Eastern Alborz were assigned traditionally to the Lashkarak Formation, as it was revised by Glaus (1965). However, as it was shown by Ghobadi Pour et al. (2011c) in the recent revision of the Ordovician stratigraphy of the Alborz Region, the lower boundary of the Lashkarak Formation, as it was originally defined by Gansser \& Huber (1962), coincides with a widespread discontinuity at the base of the Darriwilian traceable across the Ordovician sections of Alborz, therefore the Lashkarak Formation as a lithostratigraphical unit is confined to the Darriwilian and younger upper Ordovician deposits, whereas the lithostratigraphical subdivision of the Lower to Middle Ordovician part of the sequence is not formally established.

In Simeh-Kuh, cephalopod specimens were collected from two localities. Locality ' $\mathrm{T}$ '-bed (geographical coordinates $36^{\circ} 12^{\prime} 44.8^{\prime \prime} \mathrm{N}$; $54^{\circ} 13^{\prime} 30.1^{\prime \prime} \mathrm{E}$; altitude $1382 \mathrm{~m}$; Fig. 2) is a natural exposure of an olive to grey, argillaceous siltstone about $35.5 \mathrm{~m}$ thick with a thin $(0.1 \mathrm{~m})$ bed of brown bioclastic limestone at $14.4 \mathrm{~m}$ above the base of the unit (Unit L11 of Popov et al. 2008). A single specimen of Bactroceras sp. was collected from the lower part of the unit within $2 \mathrm{~m}$ below a bed of brown bioclastic limestone with conodonts characteristic of the uppermost Tremadocian Drepanoistodus aff. amoenus Subzone in the
Paroistodus proteus Biozone (Popov et al. 2008). The associated faunal assemblage includes the brachiopods Polytoechia hecatompylensis Popov et al., 2009, Paralenorthis semnanensis Popov et al., 2009, Ranorthis cheshmehaliana Popov et al., 2009 and Xinanorthis qoomesensis Popov et al., 2009, the trilobites Damghanampyx ginteri Ghobadi Pour et al., 2007b, Asaphellus fecundus Ghobadi Pour et al., 2007b, Taihungshania miqueli (Bergeron, 1894) and Asaphopsis? sp. This is the lowermost documented cephalopod occurrence in Iran.

Locality C-11 (geographical coordinates $36^{\circ} 12^{\prime} 47.6^{\prime \prime} \mathrm{N}$, $54^{\circ} 13^{\prime} 25^{\prime \prime} \mathrm{E}$, altitude 1429; Fig. 2) includes a $31 \mathrm{~m}$ interval in the uppermost of the measured section in SimehKuh, which is comprised of dark brown, fine grained, silty, calcareous sandstone. The orthocone cephalopod Protocyclendoceras sp. B was collected from loose rock within this interval. Associated faunal assemblage includes the brachiopods Pseudocrania sp., Ishimia sp. and Vellamo? sp., the trilobite Birmanites sp. and abundant echinoderms.

In Deh-Molla all cephalopod specimens were sampled from a single horizon representing a unit of brownish red calcareous argillite up to $16.6 \mathrm{~m}$ thick with several beds enriched with ferruginous oolites. Locality DM-A/11 (geographical coordinates $36^{\circ} 21^{\prime} 17.04^{\prime \prime}$; E 54 $44^{\circ} 35.16^{\prime \prime}$, altitude $1655 \mathrm{~m}$ ) contains Virgoceras? sp. C (Fig. 2), which occurs in association with abundant brachiopods, including Saucrorthis obtusa Ghobadi Pour et al., 2011c, trilobites Birmanites sp. and echinoderms (Ghobadi Pour et al. 2011c, Unit 19).

\section{Central Iran, Derenjal Mountains}

The Derenjal Mountains are situated at about $65 \mathrm{~km}$ north of Tabas (north-eastern Yazd Province). The uppermost Cambrian and Ordovician sediments in the area are referred to the Shirgesht Formation. General information on the Early Palaeozoic geology of the area can be found in publications by Ruttner et al. (1968) and by Bruton et al. (2004), but these publications lack detailed faunal logs. More data on the Middle Ordovician sequence of the Shirgesht Formation were presented in subsequent studies by Ghobadi Pour et al. (2006), Ghobadi Pour \& Popov (2009) and Ghobadi Pour \& Turvey (2009).

In the Derenjal Mountains all orthoconic cephalopods were collected from three horizons (Fig. 2, samples F-33, F-35 and F-36) in continuous Middle Ordovician sequence of the Shirgesht Formation exposed on the west side of Dahaneh Kolut Valley (Section 'B' of Ghobadi Pour \& Popov 2009, Fig. 1 and Ghobadi Pour \& Turvey 2009, Fig. 1). Geographical coordinates for the base and top of Section B are $34^{\circ} 05^{\prime} 32^{\prime \prime} \mathrm{N}$ and $56^{\circ} 47^{\prime} 7.3^{\prime \prime} \mathrm{E}$, and $34^{\circ} 05^{\prime} 21.7^{\prime \prime} \mathrm{N}$ and $56^{\circ} 47^{\prime} 06.7^{\prime \prime} \mathrm{E}$, respectively. 
Figure 1. Schematic structural map of Iran showing position of Ordovician cephalopod fossil localities discussed in the paper (mainly after Ramezani \& Tucker 2003 and Hairapetian et al. in press), with modifications; structural data compiled from various sources, e.g., Berberian \& King (1981), Lindenbreviations: AZF - Abiz fault; DRF Doruneh fault; KBF - Kuhbanan fault; KMF - Kalmard fault; MAF - Mehdiabad fault; MZT - Main Zagros thrust; NAF - Nostratabad fault; NBF - Nayband fault; NHF - Nehbandan fault; NNF - Nain fault; OKF - Ozbak Kuh fault; RVF - Rivash fault; SBF Shahre-Babak fault; SHF - Syahkuh fault; TKF - Taknar fault. berg et al. (1984) and Alavi (1991). Ab-

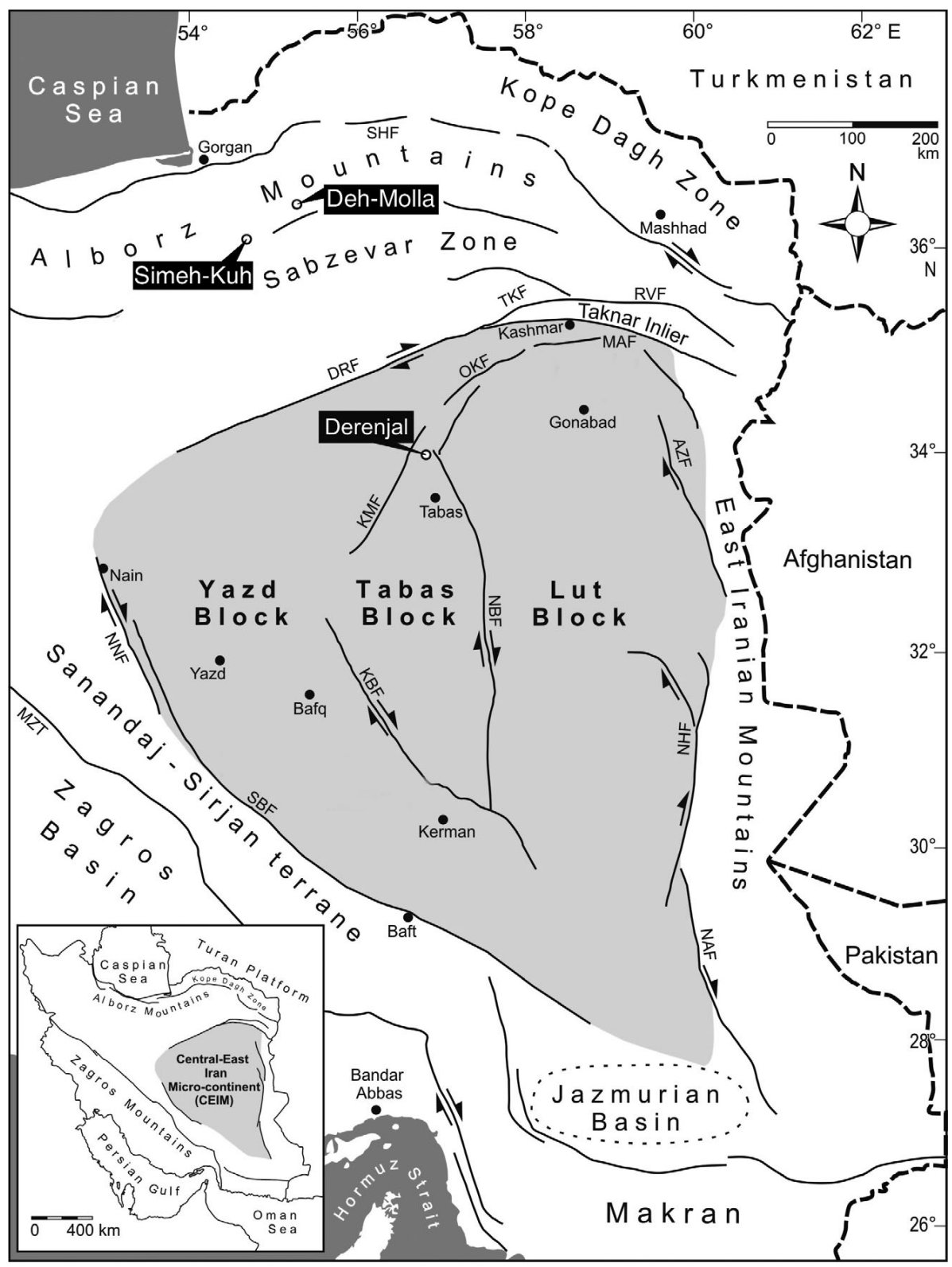

Sample F-33 is confined to the upper part of Unit B4 of Ghobadi Pour \& Turvey (2009, Figs 1, 2). It contains the orthoconic cephalopod Protocyclendoceras sp. A, which occurs in association with the trilobites Illaenus sinensis Yabe (in Yabe \& Hayasaka, 1920), Liomegalaspides kolutensis (Pillet, 1973), and Pseudocalymene superba (Pillet, 1973). The age of the sample is poorly constrained and provisionally considered as the upper Dapingian to lower Dariwillian (Ghobadi Pour \& Turvey 2009).

Sample F-35 was collected from loose rock corresponding to the entire interval of the Unit B5 after Ghobadi Pour \& Popov (2009). It contains poorly preserved specimens of Endoceratidae gen. and sp. indet. The Darriwilian age of the sample is defined by the occurrence of the trilobite Neseuretinus birmanicus (Reed, 1906) and ostracods
Aechmina? cf. ventadorni Vannier, 1986; Cerninella aryana Williams et al., 2006 in Ghobadi Pour et al. (2006); Ordovizona amyitisae Williams et al., 2006 in Ghobadi Pour et al. (2006); for more details see Ghobadi Pour et al. (2006) and Ghobadi Pour \& Popov (2009).

Sample F-36 was collected from the Unit B6 after Ghobadi Pour \& Popov (2009), which comprises brownish red sandy limestones about $19 \mathrm{~m}$ thick. It contains a moderately diverse orthoconic cephalopod assemblage, including Dideroceras sp., Gangshanoceras? sp., Sactorthoceras sp., Virgoceras? sp. A, Virgoceras? sp. B, Virgoceras? sp. C and Troedssonellidae gen. and sp. indet. Associated faunal assemblage is represented by the trilobites Neseuretinus birmanicus, Ovalocephalus kanlingensis (Zhang, 1981) [= Ovalocephalus aff. obsoletus (Zhou \& Dean, 1986) of 
Ghobadi Pour \& Popov, 2009], the ostracods Aechmina? cf. ventadorni, Cerninella aryana Williams et al., 2006 in Ghobadi Pour et al. (2006), and the rhombiferan echinoderm Heliocrinites sp.

\section{Preservation}

\section{Shirgesht Formation}

Cephalopods from the Shirgesht Formation consist largely of portions of orthocerid phragmocones, but also include a relatively small number of endocerid siphuncles and body-chambers. Only one intact endocerid phragmocone was collected. Whilst it is clear all the preserved portions of phragmocones represent shells that were broken up prior to final burial, it is less certain how much further breakage has taken place, either during collection, or in the case of material that was collected loose, through processes subsequent to the release of specimens from the matrix.

The portions of phragmocones preserved range from $8 \mathrm{~mm}$ and $82 \mathrm{~mm}$ in length with a mean of $29 \mathrm{~mm}(\mathrm{~N}=54)$. Diameters range from $5 \mathrm{~mm}$ to $40 \mathrm{~mm}$ (mean $=18.2 \mathrm{~mm}$, $\mathrm{N}=52$ ). Fragments consist of a single camera to as many as twelve camerae. Virtually all specimens show septal surfaces at either end of the fragment, but the degree of wear of the walls of the phragmocones varies greatly. Whilst there is evidence for the presence of shell sculpture in several of the taxa described below, in most specimens the surface of the phragmocone ranges from smooth with the sutures visible, to markedly corroded or worn, particularly in the vicinity of the sutures.

Where specimens have been sectioned, with a few exceptions the septa remain largely intact. However, except where endosiphuncular and cameral deposits support them (NMW 2012.15G.56, Fig. 9F), the connecting rings are almost invariably missing.

Most of the specimens are entirely invested with sediment that appears similar to that of the surrounding matrix. Several specimens also contain ostracod valves, often concentrated in large numbers on one side of the phragmocone (NMW 2012.15G.34). In the few cases where voids remain (NMW 2012.15G.64, Fig. 10A, G) these are limited to the apical end of the specimen, on what is probably the dorsal side of the shell where they are lined with what appears to be an isopachous sparite. In some of the specimens in which cameral and endosiphuncular deposits are preserved there is often strong evidence that they have developed neomorphic textures, so that in NMW 2012.15G.40 and NMW 2012.15G.64 only the surfaces of the cameral deposits remain, the cores containing patches of more coarsely granular pale and dark calcite set in a matrix similar in colour and granularity to that of the matrix within the phragmocone. In both of these specimens the portion of septum associated with the cameral deposit is dislocated, fractured or even missing, and this may suggest that some of the fine-grained material within the zone of the cameral deposits is in fact matrix.

Although the surfaces of most of the specimens are largely featureless, a few are encrusted with bryozoans and pelmatozoan holdfasts. NMW 2012.15G.18, Fig. 3C shows a bryozoan encrusting the worn surface of a phragmocone. Where parts of the bryozoan have detached from the shell the faint impression of a shell sculpture is visible. This cannot be seen anywhere else on the surface of the phragmocone. In this particular specimen, there is evidence of wear around the sutures, but the bryozoan appears to overgrow these. A pelmatozoan holdfast is visible on (NMW 2012.15G.13, Fig. 3A) that overgrows and fills the suture, which is slightly worn.

With the exception of two body-chambers belonging to (Protocyclendoceras sp. A) all remains of endocerids consist of fragments of ectosiphuncle, probably containing endosiphuncular deposits that are for the most part, no longer recognisable. In some cases, the surfaces of the siphuncles are encrusted with bryozoans and pelmatozoans (NMW 2012.15G.58, Fig. 3B) and may also show signs of borings (Fig. 5F, Q).

The observations above may be open to several interpretations. Given apical angles that range between $2^{\circ}$ and $8^{\circ}$, with maximum conch diameters of $40 \mathrm{~mm}$, some of the shells could greater than $3 \mathrm{~m}$ in length. If this is generally the case, and it is assumed that the bulk of specimens collected are no more fragmented than when they were in situ, then it would seem that the shells were broken up substantially after the death of the animals. The fact that the septa are largely intact suggests that either the phragmocones completely flooded before reaching implosion depth, or they never sank to that depth. The lack of connecting rings, combined with the fact that the septa remain largely intact suggests that the former may have decomposed to the extent that mechanical shock combined with the entry of sediment may have been sufficient to destroy them entirely; particularly given the thinness of the connecting rings, combined with the presence of glycoprotein filling pores in the inner layer (Mutvei 2002). This contention may be supported by the fact that some of the cameral deposits (e.g. NMW 2012.15G.64), also rich in glycoproteins (Gregoire \& Teichert 1965, Fischer \& Teichert 1969) appear to be so degraded that they have retained little competence, and so were replaced with sediment when the septa were ruptured.

The infilling of the majority of specimens is also an indication that fragmentation of the conch took place before burial as Seilacher (1969) demonstrated that a current was required to enter and exit the siphuncle in order that sediment could be carried into the phragmocone. This could only happen when the shell was truncated. 


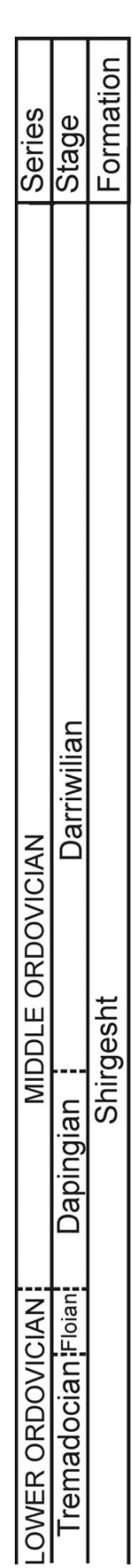

\section{Derenjal Mountains}

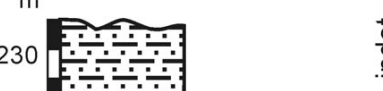

220
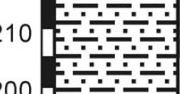

200

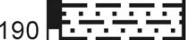

80

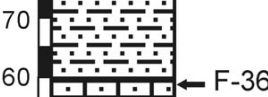

50

(40
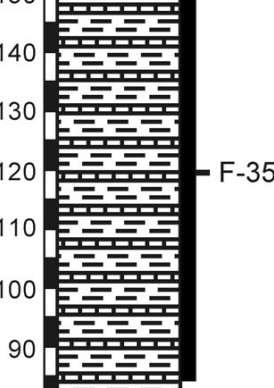

80 年:
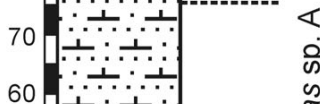

$60[\because \because \because \vdots \quad$ क

50

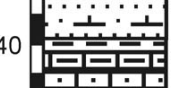

30 יं:

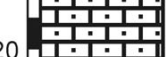

i:ंنं

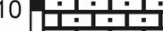

0 运:

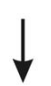

$\because:-$ Conglomerates

๖ Sandstones

F-: Sandstones and

siltstones

Argillites

Bioclastic

limestones

Argillaceous

limestones

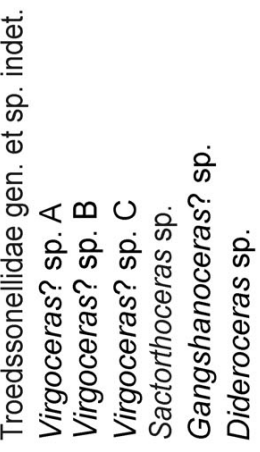

\section{Eastern Alborz}

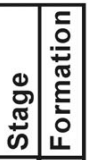

\section{Simeh-Kuh}
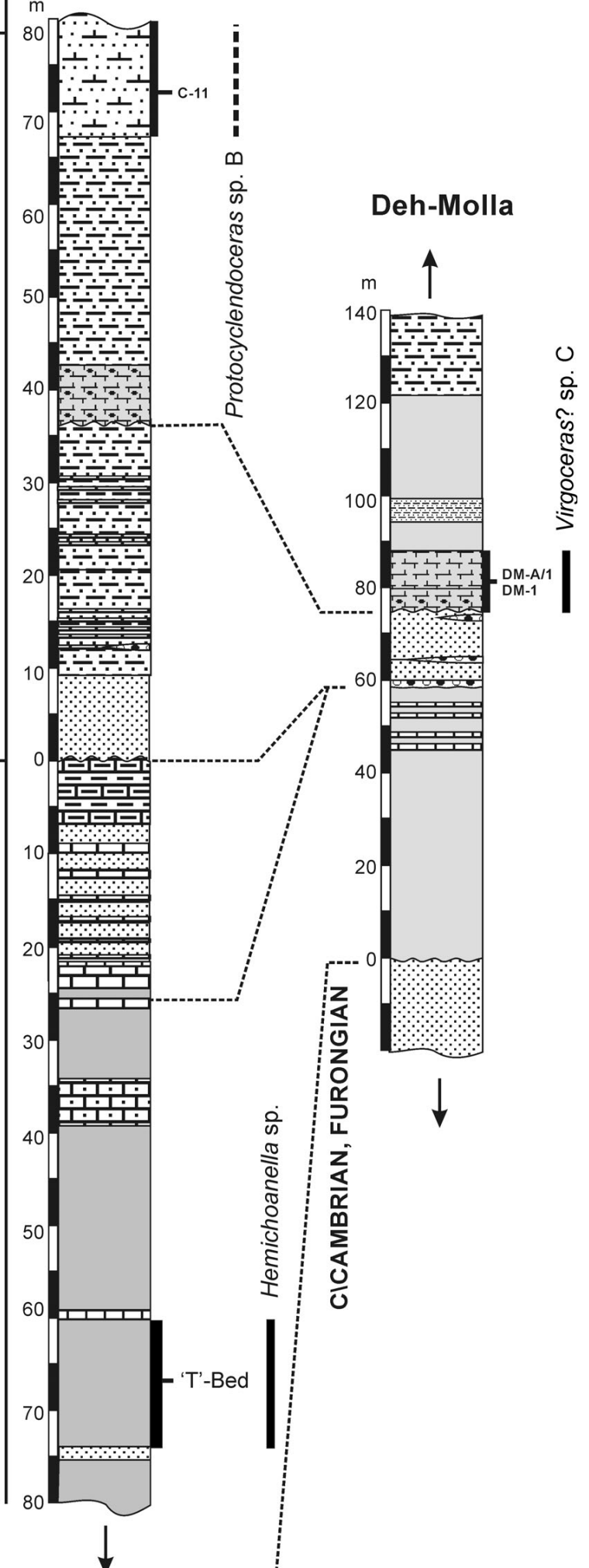

Figure 2. Stratigraphical columns of the Lower to Middle Ordovician sections in Daheneh-e Kalut (Derenjal Mountains), Deh-Molla and Simeh Kuh, showing position of the fossil samples discussed in the paper and inferred correlation of lithostratigraphical units. 


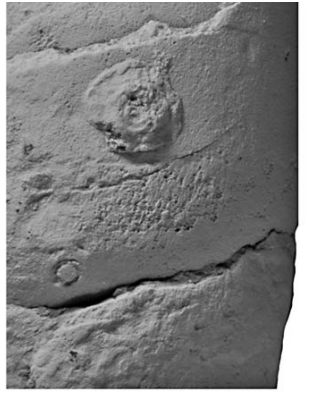

A

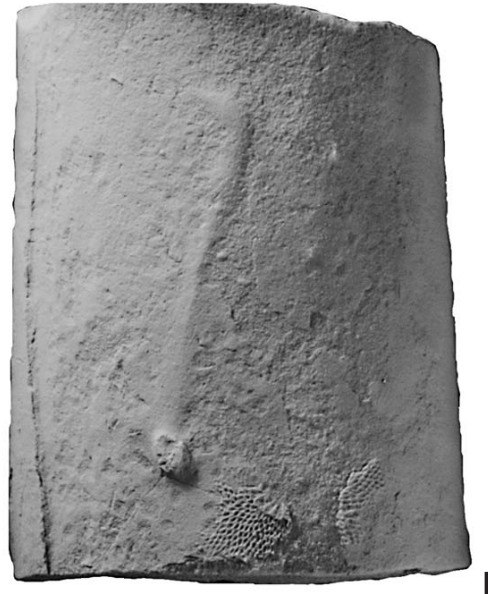

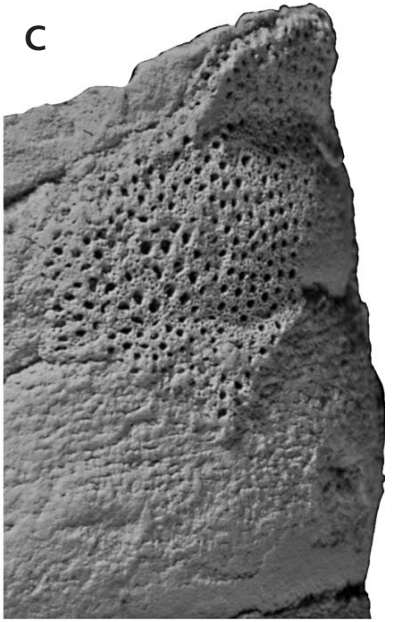

Figure 3. Epibionts on cephalopods from the Shirgesht Formation. $\bullet$ A - pelmatozoan holdfast on surface of NMW 2012.15G.13, Virgoceras? sp. $\mathrm{C}, \times 3.6$. $・ \mathrm{~B}-$ bryozoans and pelmatozoan holdfast encrusting a worn portion of probable endocerid siphuncle NMW 2012.15G.68, × 2.5. • C - bryozoan encrusting surface of shell sculpture of specimen of Virgoceras? sp. (NMW 2012.15G.18), but apparently also encrusting sutures and bare septal surfaces, $\times 4.4$.
The significance of the presence of ostracods, sometimes concentrated in large numbers within part of a camera is open to interpretation. Several associations between ostracods and ammonites or orthoconic cephalopods have been attributed to scavenging on the part of the ostracods (Weitschat 1983, Vannier et al. 1998, Gabbot et al. 2003), particularly because they occur partially or completely within body-chambers. Whilst the occurrences recorded here might be related to scavenging activities, as no body-chambers are preserved, such a relationship cannot be inferred with any confidence, and as most specimens appear to consist of disarticulated valves within the camera, it is possible that, they instead represent concentrations resulting from the winnowing of fine-grained sediment as the current passed through the phragmocone.

It is not possible to determine whether the epibionts on the orthocerid shells were pre- or post-mortal, although the presence of pelmatozoan holdfasts could suggest that they were post-mortem attachments, whilst those present on the endocerid ectosiphuncles were clearly post-mortem in origin. This, and the concentrations of ostracods in some camerae suggest that after the shells were broken, they may have been resident on the sea floor for some time. Worn surfaces of some of the internal moulds can be shown not to have arisen from recent weathering, and may suggest that that after burial, lithification took place within the phragmocone relatively early compared to the surrounding sediment. Some of these may have been exhumed and subjected to wear in the process, and it is possible that some of the epibionts (in particular the pelmatozoans) became attached at this time.

Many of the endocerids were broken up prior to burial and often only the more robust portions of the siphuncle containing endosiphuncular deposits remain.

Many specimens show a degree of deformation, and their cross-sections range from circular to elliptical. As there appears to be no evidence of shearing, this deformation is taken to have occurred during burial.

\section{Lashkarak Formation}

Although specimens from the Lashkarak Formation are also largely infilled with sediment similar to the surrounding matrix, and the connecting rings are largely missing, no specimen shows the external wear seen in some specimens from the Shirgesht Formation. Furthermore, the only endocerid recorded from the Lashkarak Formation consists of a piece of intact phragmocone. Together, these may suggest that these conchs may have been buried more rapidly than those of the Shirgesht Formation, and were not subsequently reworked.

\section{Biostratigraphical and palaeobiogeographical significance of the cephalopod assemblages}

In that part of the Gondwana margin that lay at a relatively high latitude during the Tremadoc, cephalopods are generally rare and their diversity is low. In the Montagne Noire (Kröger \& Evans 2011), a diverse Tremadocian assemblage is known to consist of Ellesmerocerida including the Eothinoceratidae, Cyclostomiceratidae and Rioceratidae; the endocerid family Proterocameroceratidae, and the earliest definite members of the Orthoceratoidea including baltoceratids, and a possible troedssonellid. Beyond the Montagne Noire the only other records of Tremadocian cephalopods along the high latitude margins of Gondwana consist of Saloceras from Avalonia (Evans 2005) and the Central Andean Basin (Cichowolski \& Vaccari 2011). Thus the presence of a probable Bactroceras in the Tremadocian of the Eastern Alborz constitutes a significant addition to knowledge of these assemblages.

The occurrence of Bactroceras in the uppermost Tremadocian of the eastern Alborz appears to be consistent with its presence at several other locations along the high latitude margins of Gondwana during the Early Ordovician 

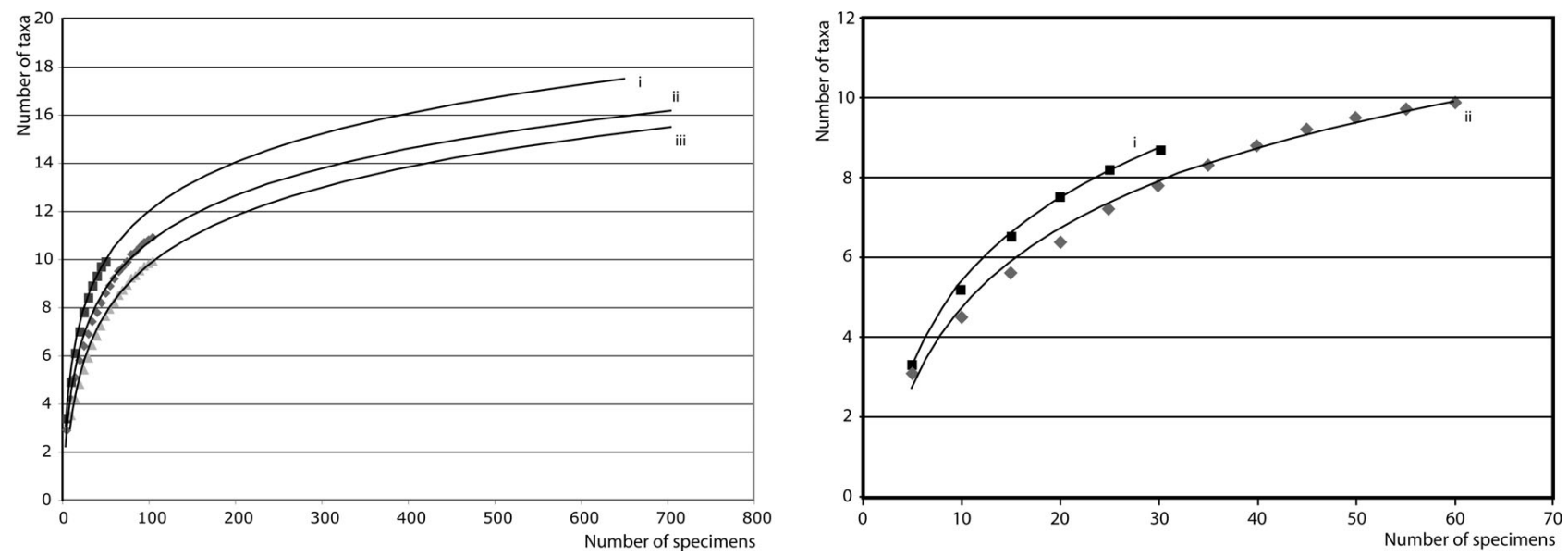

Figure 4. Rarefaction curves for cephalopod assemblages from the Shirgesht and Lashkarak formations. • A - combined data from both formations extrapolated using best-fit curves. $\mathrm{i}$ - including all specimens assigned to a taxon; ii - including all material and undetermined specimens recast proportionately to described taxa; iii - all material with indeterminate specimens treated as single taxon. • B - raw data. i - Lashkarak Formation; ii - Shirgesht Formation.

including the late early to mid-Floian Upper Fezouata Formation of the Anti Atlas of Morocco (Kröger \& Lefebvre 2012) and the late Tremadocian of St. Chinian and late Tremadocian-early Floian La Maurerie formations of the Montagne Noire (Kröger \& Evans 2011). The horizon from which the Lashkarak specimen came lies within the lowermost Drepanoistodus aff. amoenus Subzone of the Paroistodus proteus Biozone (Ghobadi Pour et al. $2007 b$, p. 489) and within the stratigraphical range of the specimens from the Montagne Noire. Similarly, the association of Bactroceras with a trilobite assemblage regarded as belonging to the Raphiophorid Biofacies (Ghobadi Pour et al. 2007b, p. 489) reflects the occurrence of the genus elsewhere in deeper shelf environments, as in the Montagne Noire (Kröger \& Evans 2011) or the Dapingian Pontyfenni Formation of South Wales (Evans 2005). Thus the presence of Bactroceras, as with the trilobite assemblage (Ghobadi Pour et al. 2007b, p. 489), suggests a high latitude affinity for this part of the Early Ordovician sequence.

The cephalopods from the Darriwilian portions of the Lashkarak and Shirgesht formations are not particularly well-preserved, often leaving uncertainty as to their correct assignment. Application of rarefaction analysis using the software package 'Analytical Rarefaction 1.4' by S.M. Holland to the material that can be assigned to a named taxon (representing approximately $46 \%$ of the total number of specimens in the combined collections) suggests that these assemblages are not particularly diverse (Fig. 4B). Including the indeterminate specimens as a single taxon or redistributing them across the most abundant taxa makes little difference to the outcome (Fig. 4A). This is also indicated by the data for the Shirgesht Formation that suggests as few as ten taxa may be present (Fig. 4B). Clearly, since some of the specimens were collected from loose material and a substantial portion of the material remains indetermi- nate, the lack of a systematic collecting process, puts the value of the rarifaction analysis in doubt, but may still provide an indication as to the real diversity of the assemblage.

Whatever the doubts with the rarefaction analysis, the presence of Protocylendoceras, Dideroceras, a troedssonellid similar to a manuscript taxon described from Scandinavia by King (1990), Virgoceras, Sactorthoceras and Gangshanoceras, may be taken to indicate connections or affinities with South China and Baltica. By comparison with the faunas of South China and Baltica, that of the Alborz is of very restricted diversity, which on current evidence lacks representatives of the Oncocerida, Tarphycerida, or Lituitida, all of which were thriving during the Darriwilian in South China and Baltica (King 1990, 1999; Kröger et al. 2009; Xiao et al. 2006).

In terms of their general composition, the assemblages from the eastern Alborz show similarities to those of the Śárka Formation of the Prague Basin, as well as other successions of Darriwilian Age in Brittany, the Valongo area of Portugal, and the Welsh Basin of England and Wales, which, with the possible exception of the latter, all require revision and description of previously undescribed material. Marek (1999) and Manda (2008) briefly reviewed the Darriwillian cephalopods of the Prague Basin; for the most part assigning them to orders, and made no attempt to further resolve those taxa that they assigned to the Orthocerida and Pseudorthocerida. With the exception of those specimens that can be clearly assigned to Bathmoceras Barrande and Bactroceras, the cephalopods from the Šarka Formation of the Prague Basin as illustrated by Barrande (1868, 1870) may be assigned to the Endocerida and Orthoceratoidea, but still require substantial revision in order to further refine their taxonomy. Marek (1999) assigned "Orthoceras" bonum Barrande to the Actinocerida. Decalcified internal moulds (Barrande 1868, pl. 247, figs 1-11) show a 
septal foramen that may be interpreted as having contained a radially divided annulosiphonate deposit that might suggest an assignment to the Actinocerida. The camerae, however, are remarkably deep for an actinocerid. Other Orthoceratoidea such as "O." primum Barrande or "O." tardigradum Barrande seem most likely to belong to the Geisonoceratidae and Sactorthoceratidae respectively. Cephalopods from Darriwilian sediments of England and Wales (Eastern Avalonia) are dominated by eothinoceratids, endocerids (mainly Dideroceras), and orthocerids that are probably assignable to the Geisonoceratidae, whilst lituitids and Bathmoceras contribute a minor element of the fauna (Evans 2005). Similar assemblages, that with the exception of Trocholites fugax Babin \& Gutiérrez-Marco (1992) consist largely of indeterminate endocerids and orthocerids were described from the Darriwilian Valongo Formation of northern Portugal (Sá \& Gutiérrez-Marco 2009), and generally similar faunas occur throughout the Iberian Peninsula (Babin \& GutiérrezMarco 1992, Evans 2000). An endocerid was recorded (Babin 1966) from a horizon of probable Darriwilian age in the vicinity of La Meignanne in the department of Maineet-Loire, whilst T. fugax and undescribed endocerids and orthocerids (including probable geisonoceratids) of a similar age from elsewhere in Brittany have been illustrated on 'Les Trilobites ordoviciens de Bretagne' website (http://www.trilobites.fr/). T. fugax is also known from the late Darriwilian Dobrotivá Formation of Bohemia, where it is associated with orthocerids, and in contrast to the early Darriwilian Šárka Formation, endocerids, actinocerids and Bactroceras are missing (Manda 2008).

Given the uncertainty in relation to the detailed composition of many Middle Ordovician high latitude cephalopod faunas, and particularly in relation to the orthocerids, it can only be stated that in a general way, the cephalopod assemblages of the eastern Alborz show similarities to those of Avalonia, Armorica and Perunica. At the generic level, elements of the Alborz fauna are common to Baltica and South China, and these same elements may be common to other high latitude faunas. However, a comprehensive study of the Orthocerida, particularly the Orthoceratidae and Geisonoceratidae of Baltica and South China is necessary before it will be possible to assign much of the relatively poorly preserved material from Avalonia, Armorica, Perunica or the Alborz with greater confidence.

\section{Systematic palaeontology}

Order Endocerida Teichert, 1933

Family Cyrtendoceratidae Hyatt in Zittel, 1900

Remarks. - King (1990) assigned several genera including Lobocyclendoceras Balashov, 1968, Paleocyclendoceras Balashov, 1968, Paracyclendoceras Balashov, 1968 and Protocyclendoceras Balashov, 1968 to the Cyrtendoceratidae on the grounds of the curvature of the shell seen in more complete specimens and the presence of connecting rings thicker than those present in the Endoceratidae where these genera were previously placed by Balashov (1968). Later, King (1999, pp. 142-144) mentioned Paleocyclendoceras, Paracyclendoceras and Protocyclendoceras in reference to the enigmatic taxon Endoceras vaginatum (Schlotheim, 1820), but made no specific comment regarding their assignment to the Cyrtendoceratidae.

\section{Genus Protocyclendoceras Balashov, 1968}

Type species. - Protocyclendoceras balticum Balashov, 1968 , p. 120, pl. 22, figs 1-3. From the Kundan Stage of Estonia. By original designation.

Figure 5. Cephalopods from the Shirgesht and Lashkarak formations. $\bullet$ A, B-E - Protocyclendoceras sp. A. A - partially flattened conch; 66; $\times 1.25$; Shirgesht Formation; B-E - dorsal, lateral (venter on left), ventral and apical (venter down) views of phragmocone; NMW 2012.15G.65; $\times 1.25$. - H-M - Protocyclendoceras sp. B. H-J, M - dorsal, lateral (venter on left) ventral and adoral (venter down) views of phragmocone; $\times 2$. K, L - polished transverse sections through phragmocone at adoral and mid-length positions respectively; NMW 2012.15G.89; $\times$ 2.5; Lashkarak Formation. - F, G - Dideroceras sp. Dorsal and lateral views of ectosiphuncle, showing linear encrustations on the surface and possible indications of a network of borings; NMW 2012.15G.71; × 1.25; Shirgesht Formation. • Q, R - endoceratid gen. et sp. indet. Lateral (venter on right) and dorsal views of ectosiphuncle, also showing traces of borings and encrustations on the surface of the ectosiphuncle; NMW 2012.15G.69; $\times 2$; Shirgesht Formation. - U, Y, Z, B* - troedssonellid gen. et sp. indet. Shirgesht Formation. U - partially crushed portion of phragmocone (see also Fig. 9F, 10F); NMW 2012.15G.58; $\times 2$. Y - lateral view of single deep camerae; NMW 2012.15G.25; $\times 1.75$. Z - apical view of same specimen showing mould of episeptal cameral deposits, venter interpreted as down; $\times 2.5$. B* - aboral view of camera showing mould of thin hyposeptal cameral deposits; NMW 2012.15G.33; $\times 2.5$. $\mathrm{A}^{*}-$ Bactroceras sp. indet. Ventral view of portion of phragmocone; NMW 2012.15G.73; $\times 2.5$. $・ \mathrm{~N}, \mathrm{O}, \mathrm{V}, \mathrm{W}, \mathrm{C}^{*}-\mathrm{F}^{*}-$ Virgoceras $\mathrm{sp}$. A. N - aboral surface of septum; NMW 2012.15G.13; $\times 1$ (see also Figs 3A, 10D); Shirgesht Formation. O - lateral view of same specimen; $\times 1$. V - small portion of phragmocone; NMW 2012.15G.54; Shirgesht Formation. W - detail of phragmocone showing ventral surface with moulds of bosses formed by episeptal cameral deposits; NMW 2012.15G.56; × 3.35 (see also Figs 8A, 10E, L). C* - portion of large phragmocone; NMW 2012.15G.12; $\times 1$; Shirgesht Formation. D* - same specimen showing septa; $\times 1 ; \mathrm{E}^{*}-$ same specimen, aboral view of septum; $\times 1$. $\mathrm{F}^{*}-$ phragmocone showing shell sculpture; NMW 2012.15G.29; × 2; Shirgesht Formation. • X - Virgoceras sp. B. Ventral view of phragmocone showing moulds of cameral deposits; NMW 2012.15G.40; × 2; Shirgesht Formation (see also Figs 5X, 9E, 10B, C). • P, S, T - Virgoceras sp. C. P - detail of shell sculpture; NMW 2012.15G.59; $\times 3.5$; Shirgesht Formation. S, T - respective probable ventral and lateral views of phragmocone; NMW 2012.15G.61; × 1; Shirgesht Formation. 
David H. Evans et al. • Review of Early to Mid Ordovician orthoconic cephalopods from Iran

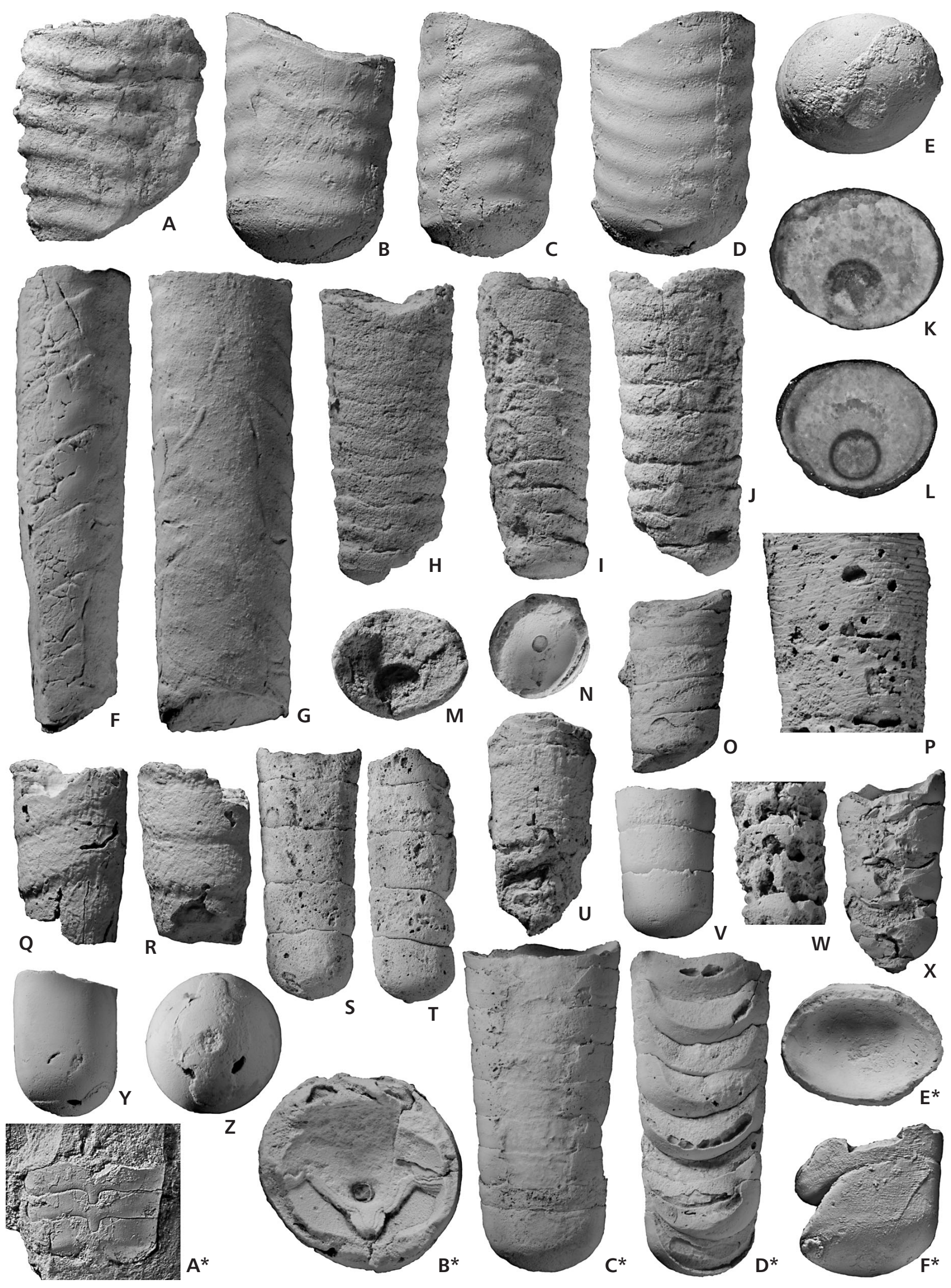


Diagnosis. - Subcircular section, depressed adorally; possessing low, transverse annulations throughout length of conch with fine or very fine lirae parallel to annulations. Sutures transverse and camerae shallow. Siphuncle ventral, 25-40\% of conch diameter. Septal necks subholochoanitic to holochoanitic; connecting rings relatively thin in older taxa but thicker in younger taxa, lining whole of septal neck. Endocones asymmetrical with 'hour-glass' shaped cross-section. Adapted from King (1990).

Remarks. - In discussing the genus, King (1990, p. 116) noted that the oldest species recorded from the Volkhovian of Öland (manuscript taxon - King 1990, p. 118, pl. 14, fig. 3 , pl. 16, figs 6,7 ) exhibited the most marked conch curvature, and probably originated from the Proterocameroceratidae. Younger taxa from horizons of Kundan age in the Baltic region generally exhibit a weaker conch curvature and less pronounced annulations.

\section{Protocyclendoceras sp. A}

Figure 5A-E

Material. - NMW 2012.15G.65 and 66, both from sampling level F-33 at the top of unit B4 of the Middle Ordovician (Darriwilian) Shirgesht Formation on the west side of Dahaneh Kolut Valley, Derenjal Mountains.

Description. - NMW 2012.15G.65 represents the apical end of a body-chamber 34 mm long. NMW 2012.15G.66 probably also represents a body-chamber, although somewhat deformed. The bulk of the description is based upon NMW 2012.15G.65, which is by far the best-preserved specimen. This individual has a rate of expansion of $5.8^{\circ}$ and a dorsoventral diameter of $19 \mathrm{~mm}$ and lateral diameter of $22 \mathrm{~mm}$, giving a slightly depressed conch crosssection. The depth of the septum at the base of the bodychamber is $31.5 \%$ that of the corresponding dorsoventral diameter. The septal foramen is circular and at $6.3 \mathrm{~mm}$ in diameter is $33 \%$ of the dorsoventral diameter of the conch. The wall of the siphuncle is removed from the conch wall by $2 \mathrm{~mm}$. Nothing is known of the structure of the siphuncle. The shell is prominently annulated. The annulations are on average $4.2 \mathrm{~mm}$ apart from crest to crest, whilst the crests and troughs are about equal in their degree of curvature and their amplitude is about $0.5 \mathrm{~mm}$. The annulations are almost directly transverse over the dorsal surface of the body-chamber, but are inclined apically towards the venter on the lateral surfaces, and form a broad sinus about $6 \mathrm{~mm}$ in depth on the ventral surface. A fine sculpture consisting of striae or threads with a density of $25 \mathrm{~mm}^{-1}$ is also present and follows the same pattern as the annulations.

NMW 2012.15G.66, although partially crushed, is sim- ilar in the pattern of the annulations although they are slightly further apart at $4.5 \mathrm{~mm}$, which may be a consequence of the crushing of the body-chamber. The surface of the shell is too badly worn to show any finer sculpture.

Remarks. - These specimens are assigned to Protocyclendoceras with some uncertainty given the similarities between several of the genera assigned to the Cyrtendoceratidae. The nature of the annulations and shell sculpture suggest that they are most similar to Protocyclendoceras. In the very fine transverse striae and inclined annulations of the conch surface, this specimen is most similar to a manuscript species described by King (1990, p. 120, pl. 15, figs 1, 2, pl. 16, fig. 8) from the early Kundan of Öland. Despite these similarities, the form described by King differs in the possession of a broader siphuncle, whilst the annulations are more distant.

\section{Protocyclendoceras sp. B}

Figures 5A-M, 10K

Material. - Single specimen, NMW 2012.15G.89 from locality C-11 of the Lashkarak Formation in Simeh-Kuh northwest of Damghan. The specimen consists of a phragmocone containing an intact siphuncle and septa, and entirely filled with sparite, which although recrystallised, shows an isopachous layer over the surfaces of the septa and siphuncle and a coarser fill within the core of the siphuncle and camerae.

Description. - This specimen consists of a portion of faintly cyrtoconic phragmocone $27 \mathrm{~mm}$ long and increasing from a dorsoventral diameter of $7.5 \mathrm{~mm}$ apically to $10.5 \mathrm{~mm}$ adorally over the length of the conch, giving an apical angle of about $6^{\circ}$. The phragmocone is elliptical and compressed in section, and the ratio of the dorsoventral diameter to the lateral diameter apically (0.74) is smaller than at the adoral end (0.86), indicating that the phragmocone may become less compressed adorally. Although worn, the surface of the phragmocone shows distinct annulations about $2 \mathrm{~mm}$ in width and up to $0.45 \mathrm{~mm}$ in amplitude apically, and increasing in distance to $2.5 \mathrm{~mm}$ adorally. The annulations are slightly inclined to the plane normal to the conch axis, so that on the dorsal side, the annulations are more adoral in position than on the ventral side. Over the dorsum itself, the annulations are deflected apically to form a sinus about $6.5 \mathrm{~mm}$ wide and $1.5 \mathrm{~mm}$ in depth. Except on the dorsum, the sutures follow the troughs of the annulations, and the depth of the camerae appears to remain fairly constant at around $27 \%$ of the dorsoventral diameter of the phragmocone. The depth of the septa are $18 \%$ that of the phragmocone diameter. The siphuncle is circular in section and its diameter lies between 
$34 \%$ and $36 \%$ that of the dorsoventral diameter of the phragmocone. The wall of the siphuncle is removed from the ventral wall of the phragmocone by about $0.65 \mathrm{~mm}$. Whilst it is difficult to distinguish different elements in the wall of the siphuncle, a dark layer is present that lines the inside of the siphuncle and extends very slightly into the camerae in the vicinity of the septal foraminae. Occasionally, a thin translucent layer can be distinguished on the cameral side of the siphuncle wall that is here interpreted as the septal neck. As the darker layer extends almost the length of the siphuncle segment, its structure is interpreted as holochoanitic, with the connecting ring lining the length of the septal neck and originating on the septal surface just within the camerae. Although the siphuncle is entirely infilled with relatively coarsely crystalline calcite, in cross-section, a radial fabric appears to be present, whilst the fact that such a broad siphuncle contains calcite may also suggest that endosiphuncular deposits are present. At the adoral end of the siphuncle the section is discoloured by yellow-brown calcite forming an inverted and elongated tear-shaped cross-section rising from the ventral wall of the siphuncle. This may indicate the shape of the transverse cross-section of the endosiphocone, but some doubt remains given the coarsely crystalline nature of the siphuncular fill.

Remarks. - The structure of the siphuncle, combined with the possibly presence an endosiphocone with and elongate, tear-shaped cross-section of the siphuncle suggests that the assignment of this specimen to Protocyclendoceras is appropriate. By comparison with $P$. sp. A, the annulations, whilst inclined, slope in the opposite direction, with a broad sinus over the venter as opposed to the dorsum.

Family Endoceratidae, Hyatt, 1883

Genus Dideroceras Flower, 1950 in Flower \& Kummel (1950)

Type species. - By original designation, Endoceras wahlenbergi Foord, 1887, from the Hølen Limestone Formation (Kundan) of Kinnekulle, Västergötland, Sweden.

\section{Dideroceras sp.}

Figure 5F, G

Material. - NMW 2012.15G.71 from sampling level F-36 at the top of unit B6 of the Shirgesht Formation, Dahaneh Kolout, Derenjal Mountains, Tabas.

Description. - This specimen consists of the mould of a siphuncle $66 \mathrm{~mm}$ long, which is worn on one surface so that the cross section appears to be deformed. It is almost certainly not deformed, and the section is slightly depressed, with an apical dorsoventral diameter of $19.5 \mathrm{~mm}$ and estimated lateral diameter of $20.5 \mathrm{~mm}$. The respective measurements at the adoral end of the siphuncle are $20.5 \mathrm{~mm}$ and $21.5 \mathrm{~mm}$, giving a rate of expansion of less than $1^{\circ}$. The septal foraminae are on average $10 \mathrm{~mm}$ apart, giving a relative distance of 0.49 that of the siphuncle diameter, and are displaced across the diameter of the siphuncle by $37^{\circ}$. The mould of the surface of the segment shows that the profile is weakly convex in the apical half of the segment and concave in the adoral half. The relative smoothness of the mould at the septal foramen suggests that it represents the cameral facing termination of the connecting ring, whilst the shape of the mould and lack of other sutures along the segment suggests that the septal necks were macrochoanitic, with a connecting ring lining the septal neck.

Remarks. - Despite no other part of the phragmocone being preserved, and the lack of any endosiphuncular deposits, the overall shape of the ectosiphuncle, particularly in the almost tubular profile of the segments and the marked saddle formed by the ventral trace of the septal neck [e.g. Dideroceras amplum Balashov, 1968, pl. 11, 3b; D. rectestrigatum (Schröder), Balashov 1968, pl. 26, fig. 3b] is characteristic of the genus.

\section{Endoceratidae gen. et sp. indet.} Figure 5Q, R

Material. - NMW 2012.15G.67 and 69 from sampling level F-35, unit B5 of the Shirgesht Formation, Dahaneh Kolut, Derenjal Mountains, Tabas.

Description. - NMW 2012.15G.67 and 69 consist of very short fragments of siphuncle, $7.5 \mathrm{~mm}$ and $14 \mathrm{~mm}$ in diameter respectively. The former specimen consists of about three segments, whilst the distances between septal foraminae are $3.9 \mathrm{~mm}$ or 0.52 of the diameter of the siphuncle. The septal foramen is marked by a narrow and smooth groove inclined dorsoventrally at $24^{\circ}$ to the plane normal to the conch axis. The overall shape of the segments is almost tubular to slightly inflated, with a convex profile. The adoral end of the specimen shows the remains of an endosiphocone about $1.87 \mathrm{~mm}$ in diameter that appears to be surrounded by endocones. NMW 2012.15G.69 also consists of three siphonal segments each about 0.49 of the diameter of the siphuncle in length. The septal foraminae are inclined to the normal of the axis of the siphuncle at about $27^{\circ}$, and the outlines of the segments show a marked convex profile just adorally of the septal foramen, which then becomes concave towards the next segment. 
Remarks. - It is possible that these specimens represent parts of the siphuncle of Protocyclendoceras sp. described above. However, with the exception of NMW 2012.15G.67, the diameters of the other two siphuncles are much greater than that seen in Protocyclendoceras sp. described above. That these specimens come from a different horizon to those of Protocyclendoceras sp. may also be of significance. The distance between septal foraminae, their angle of declination, and the overall shape of the segments all suggest that they belong to the same taxon, and in the relatively long distance between the septal foraminae these specimens may show a degree of similarity to Ventrolobendoceras Balashov, 1968.

Subclass Orthoceratoidea Zhuravleva, 1994

Order Dissidocerida Zhuravleva, 1964

Family Troedssonellidae Kobayashi, 1935

Troedssonellid gen. et sp. indet.

Figures 5U, Y, Z, B*, *A, 6, 9F, 10F

Material. - NMW 2012.15G.20, 25, 33, 58. All from sampling level F-36, unit B6 of the Shirgesht Formation, Dahaneh Kolut Valley, Derenjal Mountains, Tabas.

Description. - All five specimens consist of short portions of phragmocone ranging in diameter from $8 \mathrm{~mm}$ to $19 \mathrm{~mm}$. They are characterised by their relatively small apical angle $\left(2^{\circ}\right)$ and deep camerae, which decrease in depth from juvenile portions (124\% of phragmocone diameter in NMW 2012.15G.25) to more adult fragments (depth $75-50 \%$ of the phragmocone diameter. The diameter of the siphuncle lies between $13 \%$ and $15 \%$ that of the phragmocone, whilst the position of the siphuncle lies at about $46 \%$ of the way across the diameter of the phragmocone.

NMW 2012.15G.58 consists of one relatively undamaged camera and two camerae, which have been partially crushed. This is the only specimen where a largely intact siphuncle is preserved and where endosiphuncular deposits remain visible as a calcareous lining. At the septal foramen, the diameter of the siphuncle is $13 \%$ that of the phragmocone whilst its centre is situated about two-fifths of the way across the phragmocone towards the venter. The septal necks are orthochoanitic and the connecting ring almost tubular, but very slightly inflated just apicad of the septal necks. There appears to be a calcareous lining within the siphuncle on the side closest to the shell wall, and may be weakly developed apically on the other side of the siphuncle. The lining gradually thickens in an apical direction, and a laminated fabric parallel to the surface of lining can be seen within parts of the lining. The lining may also be slightly thickened in the vicinity of the septal necks.
Cameral deposits consist of episeptal and mural deposits that originate in the vicinity of the suture and develop adorally and towards the conch axis. Fragments of the shell sculpture that remain on the surface of the specimen consist of narrow transverse grooves estimated to be $0.025 \mathrm{~mm}$ in width, with a density of 4 per $\mathrm{mm}$.

Of the remaining specimens, NMW 2012.15G.25 and 33 provide additional information in relation to the distribution of the cameral deposits. The surface of septum at the apical end of NMW 2012.15G.25 shows what are here interpreted to be the moulds of very thin episeptal deposits (Fig. 6A). These consist of a shallow circular flange that surrounds the septal foramen but extends dorsally and ventrally across the septum as a pair of bilaterally symmetrical processes. One of the processes is broader and more rounded than the other, and in the intersections between the central boss and this process there are two small hemispherical moulds that would form small adorally projected bosses to either side of the dorsoventral plane of the phragmocone. As such structures are often seen on the ventral surface of episeptal deposits in other orthoceratoids (Evans 2005, text-fig. 16c, pl. 5, fig. 4), the side with the broader projection is regarded as ventral.

A similar, but more poorly preserved mould is present on the apical surface of NMW 2012.15G.33. The adoral surface of the same specimen exhibits a mould of the cameral deposits that differs from those on the apical surface. In the plane normal to the axis of the shell, the mould forms a pair of symmetrical masses lying to either side of the siphuncle, and on the side lying closest to the phragmocone wall, they are connected by a narrow isthmus ventrad of the siphuncle. In the zone ventral and lateral to the siphuncle, the surface of the mould indicates that in these areas, the cameral deposits were mammilate in form. The extreme lateral areas of the mould consist of a series of fine terraces that may reflect the internal lamination of the cameral deposits. The sense in which the terraces slope would be consistent with an interpretation as hyposeptal deposits (Fig. 6B).

Remarks. - These specimens are united by the similarity of their general morphology both in terms of their low apical angles, deep camerae and the relative diameter and position of the siphuncle. The endosiphuncular deposits seen in NMW 2012.15G.58 are here interpreted as a lining, and considered to indicate a troedssonellid affinity. In the possession of very deep camerae, these specimens are similar to an un-named troedssonellid described by King (1990, p. 161 , pl. 20 , figs 10,11 , pl. 21 , figs 9 , 10, pl. 22, figs $6-8$, text-fig. 3.15b) from Scandinavia ranging from the early Kundan to Aserian Stages of Sweden. It differs from this form mainly in the less eccentric position of the siphuncle, and the apparently stronger development of the cameral deposits. 
Order Orthocerida Kuhn, 1940

Family Baltoceratidae Kobayashi, 1935

\section{Genus Bactroceras Holm, 1898}

Type species. - Bactroceras avus Holm, 1898, from the Red Lituites Limestone of Öland and Vastergötland. By subsequent designation of Glenister (1952, p. 90).

\section{Bactroceras sp.}

Figure $1 \mathrm{~A}^{*}$

Material. - A single specimen, NMW 2012.15G.73, from the 'T'-bed of Simeh-Kuh, Damghan. The specimen is a fragment of the internal mould of a phragmocone that may be partially phosphatized, and although there are no obvious cracks or fractures, the specimen appears to be partially flattened, as the profile of the exposed ventral half of the phragmocone possesses a markedly elliptical rather than circular outline.

Description. - This specimen is a short length of phragmocone $7 \mathrm{~mm}$ long, and increases in diameter in the lateral plane from $7.13 \mathrm{~mm}$ to $7.46 \mathrm{~mm}$ over a distance of $5.7 \mathrm{~mm}$, indicating a rate of expansion of about $4^{\circ}$. Cameral depth is about $23 \%$ that of the phragmocone diameter, whilst the depth of the septa are estimated at $22 \%$ of the diameter of the phragmocone. The sutures appear to be straight and directly transverse but form broad, very shallow, saddles either side of a prominent ventral lobe, about $0.95 \mathrm{~mm}$ across and $0.9 \mathrm{~mm}$ deep, or approximately 0.45 of the depth of the camerae. The siphuncle is marginal, and as the ventral lobe indicates, is almost in contact with the shell wall. Its diameter is $19 \%$ that of the phragmocone.

The siphuncle protrudes from the apical end of the specimen, where it appears to be tubular in profile, and for its preserved length, shows no indication of a suture or join of any kind that might indicate the boundary between the septal necks and the connecting ring. Nor is any suture seen on the portions of siphuncle visible at the sutural lobes. The lack of sutures may suggest that the septal necks are hemichoanitic to subholochoanitic in length. However, the portion of siphuncle belonging to the most apical septum, whilst poorly preserved, appears to have broken off, possibly prior to burial. If the position of the break coincides with the join between the septal neck and the connecting ring this would suggest that septal necks were orthochoanitic with the ventral side of the septal neck being substantially longer in order to accommodate for the marginal position of the siphuncle on a relatively deep septum as seen in Bactroceras avus Holm (1898, pl. 18, figs 2, 3).

Remarks. - The identity of this very fragmentary specimen is open to question, particularly because of the difficulty in interpreting the structure of the siphuncle. This specimen may potentially be assigned to Rioceras Flower, 1964 or Hemichoanella Teichert \& Glenister, 1954. However, it differs from Rioceras in possessing tubular siphuncular segments rather than segments that are constricted between the septal foraminae. The holotype of Hemichoanella was originally referred to Baltoceras Holm by Teichert \& Glenister (1952), who then included Hemichoanella in the Baltoceratidae (Teichert \& Glenister 1954, p. 193) regarding it as "a particularly advanced baltoceratid", possessing hemichoanitic septal necks as opposed to the orthochoanitic septal necks of Baltoceras (= Cochlioceras Eichwald 1860). The hemichoanitic septal necks of Hemichoanella may suggest that an assignment to the Proterocameroceratidae or Thylacoceratidae may be more appropriate. The siphuncle of Hemichoanella is broader than that seen in most specimens assigned to Bactroceras (Evans 2005, text-fig. 8d), suggesting that an assignment to Bactroceras is plausible. Only additional material that can be sectioned will resolve the uncertainty with regard to the length of the septal necks in this specimen.

\section{Family Geisonoceratidae Zhuravleva, 1959}

Remarks. - Generally, the Geisonoceratidae consist of orthoconic longicones containing a relatively narrow, subcentrally to centrally placed siphuncle. The septal necks are orthochoanitic to suborthochoanitic, and the connecting rings weakly inflated. Endosiphuncular deposits originate as annuli at the septal necks and sometimes extend along the connecting ring to fuse and form a lining apically. A combination of episeptal, mural and hyposeptal cameral deposits are usually present. The surface of the shell may be smooth, or covered in transverse ridges and grooves.

Taxa conforming to the description above are recorded from the late Floian of the Southwestern United States (Flower 1962, Hook \& Flower 1977) and the Precordillera of Argentina (Kröger et al. 2007). Several Middle Ordovician representatives were described from Scandinavia (King 1990, Kröger 2004), China (Chen 1984) and Avalonia (Evans 2005). Despite this relatively broad distribution, the systematics of the early members of the Geisonoceratidae is relatively poorly known. Both King (pers. comm. 2011) and Kröger (2004, pers. comm. 2010) have remarked upon the abundance and diversity of Scandinavian Middle Ordovician orthocerids, and large unstudied collections, such as those held in the Naturhistoriska Riksmuseet, in Stockholm, which may make a significant contribution to unravelling the systematics of this group of cephalopods. Without such a study, a more precise assessment of the systematics of the specimens from the Shirgesht Formation will remain uncertain, and as a consequence, the material described below may be taxonomically over-split and assignments are tentative. 


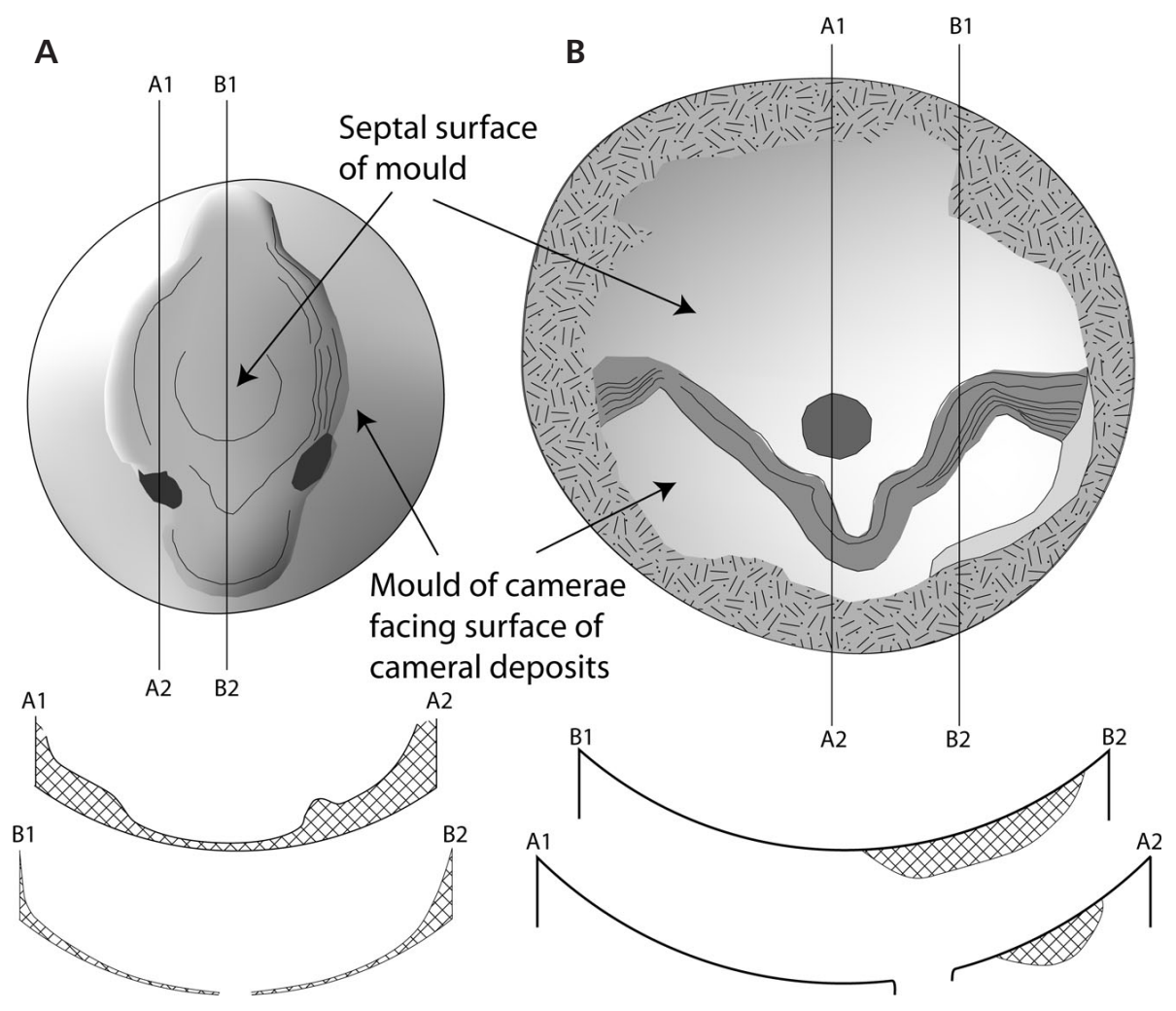

Genus Virgoceras Flower, 1939

[? = Archigeisonoceras Chen, 1984]

Type species. - Orthoceras palemon Barrande 1870, pl. 394, from the Silurian of Bohemia. By original designation.

Diagnosis. - Uncompressed orthocones with straight transverse sutures and surface marked by fine oblique or transverse and (in some species) longitudinal lines. Siphuncle central or subcentral, orthochoanitic; siphuncular deposits of annulosiphonate deposits fusing to form continuous siphuncular lining (after Sweet 1964, p. 238).

Remarks. - Although the type species of Virgoceras is $\mathrm{Si}$ lurian in age, King (1990) assigned several species from the Volkhovian and Kundan Stages of Sweden to this genus, as he was unable to distinguish the internal morphology of these forms from that of Virgoceras. Whilst the taxa that King assigned to Virgoceras show some variation in the form of the conch sculpture, King noted that Flower (1939, p. 162) had placed little emphasis on this character and described $V$. cancellatum, a species with a cancellate shell sculpture from the Silurian of Westport, Indiana.

Chen (1984) proposed Archigeisonoceras for forms similar to Geisonoceras but with slighter endosiphuncular annuli, and lacking any obvious conch sculpture; describing two species (A. elegatum and A. robustum) from the Middle Ordovician Quanshang Formation of southern Xizang (Tibet). In overall form, the two species described by Chen are
Figure 6. Explanatory diagram and interpretation of the mouldic surfaces seen in troedssonellid gen. et sp. indet. - A apical view of apical septum (see also Fig. 5Z) showing interpretation of mould as episeptal deposits and two hypothetical sections (A1-A2, B1-B2) through the deposits. Parallel lines mark terrace features considered to represent growth increments in the cameral deposits; NMW 2012.15G.25, ×6.25. • B - adoral view of adoral septum (see also Fig. 5B*) showing interpretation of mould as hyposeptal cameral deposits also exhibiting structures interpreted as growth increments; NMW 2012.15G.33; ×6.25. not dissimilar to Virgoceras, although the endosiphuncular deposits appear to be restricted to annuli at the septal necks, whilst the surface of the conch was reported to lack any sculpture. Several additional species from the Volkhovian, Kundan, Aserian and Lasnamägian of Öland were ascribed to Archigeisonoceras by Kröger (2004). Whilst the conch sculpture seen in these species is smooth (or with very slight growth lines), Kröger reported that the endosiphuncular deposits either formed a lining in addition to the annuli at the septal necks, or the annuli were seen to fuse through growth apically. In the latter character, these taxa are not dissimilar to those forms that King assigned to Virgoceras.

Although Chen's (1984) diagnosis of Archigeisonoceras refers to the smaller size of the endosiphuncular annuli, Kröger's description of Scandinavian species may suggest that Archigeisonoceras is a junior synonym of Virgoceras.

\section{Virgoceras? sp. A}

Figures 5N, O, V, W, C*, D*, E*, F* , 8A, B, M, O, 9B, D, 10A-E, L

1981 Orthoceras vagans Salter. - Kalantari, pl. 2, figs 5-14.

Material. - NMW 2012.15G.12-14, 18, 21, 22, 29, 47, 49, 50, 54-57, 60, 64. From collecting horizon F-36, unit B6 of the Shirgesht Formation, Dahaneh Kolut, Derenjal Mountains, Tabas. NMW 2012.15G.74, 75, from locality 
DM-A/11, unit 19 of the Lashkarak Formation, DehMolla, Shahrud.

Description. - This material consists of several portions of phragmocone ranging from $10-80 \mathrm{~mm}$ in length and $5-40 \mathrm{~mm}$ in diameter. The cross-section of the shells is circular to very slightly subcircular and the rate of expansion of the shell varies between $5^{\circ}$ and $8^{\circ}$, but appears to decrease slightly with the growth of the shell. The depth of the camerae varies between $23 \%$ and $78 \%$ (mean $46 \%$ ) of the diameter of the shell, but shows no consistent variation in relation to conch diameter. Septal depth lies between $21 \%$ and $31 \%$ (mean 26\%) that of the phragmocone diameter. Such estimates are unreliable because of the state of preservation of many of the specimens, although there appears to be a trend towards deepening septa with an increase in the conch diameter. The shell sculpture is preserved in NMW 2012.15G.29 (Fig. 5F*) where it consists of transverse, imbricate striae with a density of 6 per $\mathrm{mm}$ that appear to have a very slightly raised lip at the adoral end of each striae.

The relative diameter of the siphuncle at the septal foramen ranges from $7 \%$ to $14 \%$ of the phragmocone diameter (mean 10.6\%) but generally decreases with the diameter of the conch. The centre of the septal foramen ranges from a slightly subcentral position (48\% of the way across the phragmocone diameter) to a more eccentric position (35\% of the way across the phragmocone diameter towards the venter). There is no evidence for any consistent variation in the position of the siphuncle during ontogeny, and the siphuncle seems to remain in a slightly subcentral position in the ventral half of the phragmocone throughout growth.

Septal necks are initially achoanitic to loxochoanitic (NMW 2012.15G.56), but become suborthochoanitic (NMW 2012.15G.64) and then orthochoanitic in the more adoral part of the phragmocone (NMW 2012.15G.47). Although the connecting rings are not preserved in any of the specimens that were sectioned, the presence of suborthochoanitic septal necks in two specimens (NMW 2012.15G.13, 64; Fig. 10A, D, G) suggest that the connecting rings were at least slightly inflated.

Three specimens possess cameral deposits (NMW 2012.15G.56, 60, 64), of which two (NMW 2012.15G.56, 64) were sectioned and show the presence of episeptal and mural deposits. On the surfaces of the internal moulds where all calcareous material has been dissolved, the moulds of the cameral deposit surfaces exhibit distinct mammilate textures. The sectioned specimens and the internal moulds provide clear evidence that the cameral deposits are better developed on the ventral and ventro-lateral sides of the phragmocone and that the deposits are most strongly developed on either side of the venter where they form a pair of ventro-lateral bosses (e.g. NMW 2012.15G.56; Figs 5W, $8 \mathrm{~A})$. A distinct septal furrow is visible on the mural surfaces of the camerae in NMW 2012.15G.60 (Fig. 7O).
Remarks. - The specimens described above, as well as Virgoceras? sp., B. and V.? sp. C (described below) are distinct from other orthoceratoid taxa described here from the Shirgesht Formation, either in the low apical angles combined with deep camerae (troedssonellid gen. et sp. indet., above), morphology of the siphuncle (Gangshanoceras? sp., below). However, the fragmentary and relatively poor preservation of this material is such that it is difficult to be confident in distinguishing between the three taxa. Many of the distinctions between these taxa appear to be insignificant, and as consequence, any attempt at separating this material is extremely subjective and mainly based on a small number of discrete characters, combined with extrapolations based on gross morphology to other specimens in which these discrete characters are not preserved or not evident.

Thus, although no endosiphuncular deposits have been observed in those specimens assigned to Virgoceras? sp. A, no specimen assigned to the species shows the presence of hyposeptal cameral deposits. There is also some evidence for ontogenetic change in the form of the septal necks in $V$. ? sp. A, whilst slight differences in the nature of the shell sculpture are apparent between $V$. ? sp. A and $V$. ? sp. C. Although V.? sp. A shows no evidence of the presence of endosiphuncular deposits, $V$. ? sp. B possesses well-developed annuli at the septal necks, and $V$.? sp. C exhibits small endosiphuncular annuli combined with parietal linings. $V$. ? sp. C also appears to show a distinct decrease in the relative diameter of the septal foramen as the diameter of the phragmocone increases. Finally, the plot of the distribution of apical angle against cameral depth (Fig. 7E) suggests that $V$.? sp. A and $V$. ? sp. C may be strongly discriminated, but this has to considered against the large background of residual material that could not be used because only one or other parameter was available for measurement.

Of those species previously assigned to Archigeisonoceras, only A. picus Kröger, 2004 and possibly A. robustum Chen, 1984 show any similarity in the rate of expansion of the shell and the depth of the camerae to the specimens described above. Despite the lack of endosiphuncular deposits, the specimens described here may be similar to forms where the hyposeptal deposits appear to be strongly suppressed and assigned to Virgoceras by King (1990); in particular one manuscript species described by King (1990, p. 165 , pl. 5 , fig. 5 , pl. 23 , figs 3 , 4, pl. 26, figs $1-6$, text-fig. 3.16a) from the early Kundan of Öland.

\section{Virgoceras? sp. B}

Figures 5X, 7C, I, 9E, 10B, C

Material. - NMW 2012.15G.11 and 40. From collecting horizon F-36, unit B6 of the Shirgesht Formation, Dahaneh Kolut, Derenjal Mountains, Tabas. 
Description. - NMW 2012.15G.11 consists of the internal mould of a phragmocone $75 \mathrm{~mm}$ long with a mean diameter of $20 \mathrm{~mm}$ and a rate of expansion of $6^{\circ}$. Cameral depth ranges from $30-40 \%$ that of the phragmocone diameter. The diameter of the siphuncle at the septal foramen is $7.5 \%$ that of the phragmocone, whilst its position is almost central. The specimen represents an adoral portion of the phragmocone and has not been sectioned, but the phragmocone walls show no evidence for the presence of cameral deposits.

The phragmocone represented by NMW 2012.15G.40 has been sectioned. It is $33 \mathrm{~mm}$ long with a mean diameter of $11 \mathrm{~mm}$ and a rate of expansion of $8^{\circ}$. The cameral depth is $45 \%$ that of the phragmocone diameter, whilst the diameter of the siphuncle at the septal foramen is about $13 \%$ that of the phragmocone, and it is positioned two fifths of the way across the diameter of the phragmocone. The septal necks are suborthochoanitic, but the connecting rings are not preserved. Endosiphuncular deposits are present but appear to be restricted to discrete annuli at the septal necks. What little is seen in this specimen suggests that the endosiphuncular annuli may remain restricted to the septal foramen during later growth of the shell. Cameral deposits are evident in the form of moulds on the surface of the phragmocone where they show mammilate surfaces and appear to be restricted to the venter (Fig. 5X). Both episeptal and hyposeptal cameral deposits are evident in the cut section (Figs 9E, 10B, C).

Remarks. - Virgoceras sp. B differs from V. sp. A in the presence of annulosiphonate deposits and hyposeptal cameral deposits. The relative depth of the camerae may also be slightly greater. Given the numbers of specimens involved, none of these differences are necessarily significant, and those seen might be accounted for by variation in the ages of the individual's collected as well as natural variation in the population.

\section{Virgoceras sp. C}

Figures 5P, S, T, 8G, H, J-L, P, R, 9F, G, 10H, I

Material. - NMW 2012.15G.77-79, 80-82, 90, 92, 95, 106, 109, 111, from locality DM-A/11, unit 19 of the Lashkarak Formation, Deh-Molla, Shahrud. NMW 2012.15G.15, 19, 59, 61. From collecting horizon F-36, unit B6 of the Shirgesht Formation, Dahaneh Kolut, Derenjal Mountains, Tabas.

Description. - These specimens consist of portions of orthocone of varying length and ranging from $7 \mathrm{~mm}$ to $26 \mathrm{~mm}$ in diameter. The cross-section of the conch is circular. The apical angle varies from $2^{\circ}$ to $8^{\circ}$ with a mean of $5^{\circ}$. The depth of the septa varies from $18 \%$ to $36 \%$ (mean $0.25 \%$ ) and there may be a very weak trend towards the in- crease in septal depth with conch diameter. Cameral depth ranges from $34 \%$ to $61 \%$ (mean 50\%) of the diameter of the conch, and there appears to be a general decrease in depth with increasing conch diameter. The diameter of the siphuncle at the septal foramen decreases from $20 \%$ of the phragmocone diameter at a diameter of $5 \mathrm{~mm}$ to $6 \%$ at a diameter of $20 \mathrm{~mm}$ (mean $11.55 \mathrm{~mm}$ ) giving a correlation $\left(\mathrm{R}^{2}\right)$ of the conch diameter with the siphuncle diameter of 0.537 . The position of the centre of the siphuncle varies between $30 \%$ and $47 \%$ of the way across the diameter of the conch towards the venter (mean $37 \%$ ) but there is no evidence of a consistent trend of siphuncle position with the growth of the phragmocone.

Only one specimen (NMW 2012.15G.59) provides evidence of the conch sculpture. This specimen shows transverse striae with a density of 2.8 per $\mathrm{mm}$ that are weakly imbricated in an adoral direction, but with a distinct but narrow and shallow groove developed between the striae.

Cameral deposits are present in three specimens, NMW 2012.15G.59, 77 and 78. In NMW 2012.15G.59, continuous episeptal and mural deposits combined with discrete hyposeptal deposits are present. In this specimen the hyposeptal deposits appear to originate in a zone close to the septal foramen and then extend laterally, so that the part of the deposit closest to the siphuncle may be inflated into a boss. NMW 2012.15G.78 (Figs 8J, K, 9G, 10I) is an internal mould of a phragmocone consisting of four camera that on the ventral side are deeply weathered, reflecting the dissolution of the cameral deposits. The internal mould, which has been sectioned shows continuous episeptal and mural deposits, whilst hyposeptal deposits are most thickly developed towards the axis of the conch, indicating an origin in this area. Where preserved as moulds, the surfaces of the cameral deposits show a highly ordered, finely mammilate surface in which mammilae form almost regular rows.

NMW 2012.15G.77 (Figs 8G, H, 9F, 10H) is also an internal mould consisting of five camerae constituting the dorsal portion of the phragmocone, and most of the ventral portion containing cameral deposits has been lost through dissolution. The mouldic surface created by the loss of the cameral deposits shows the presence of episeptal deposits forming a pair of prominent bosses either side of the siphuncle, and a similar, but less prominent pair of bosses on the hyposeptal surface. In section, episeptal deposits are visible on the dorsal side of the shell, where they are present about midway between the dorsal wall and the siphuncle, thickening abruptly a short distance from the siphuncle, but then thinning rapidly towards the dorsum.

The same three specimens provide evidence of the structure of the siphuncle. In all three specimens the septal necks appear to be orthochoanitic, but very short. The connecting rings are tubular but slightly expanded, reaching 1.5 times the diameter of the septal foramen in 

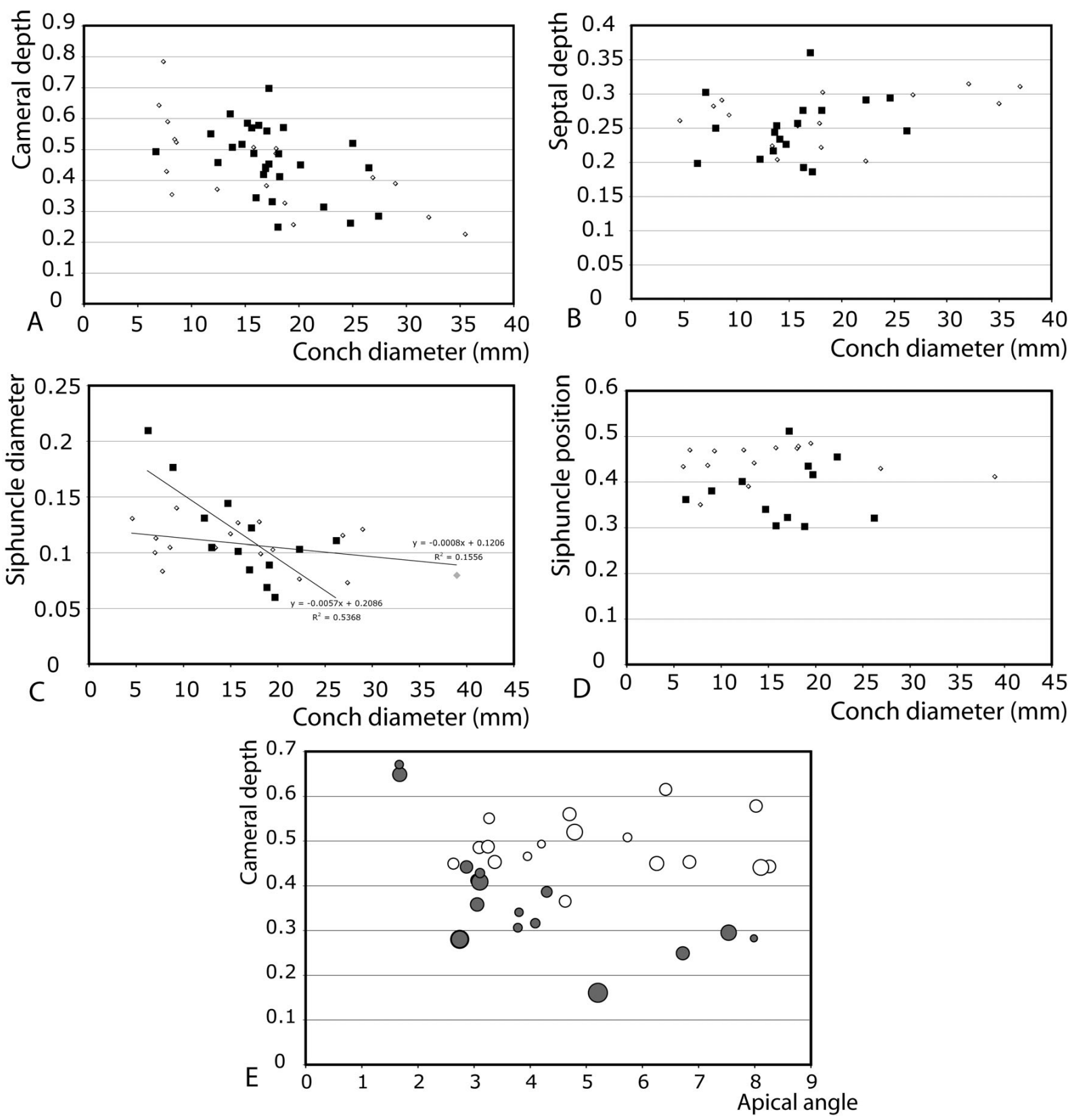

Figure 7. Variation of characters in Virgoceras? sp. A and Virgoceras? sp. C. • A - variation of cameral depth with phragmocone diameter. $\bullet$ B - variation of septal depth with phragmocone diameter. $\bullet \mathrm{C}$ - variation of siphuncle diameter with phragmocone diameter. $\bullet \mathrm{D}-\mathrm{variation}$ of the position of the siphuncle with phragmocone diameter. All values given as proportions of the phragmocone diameter. Open circles $=$ Virgoceras sp. A, filled squares $=$ Virgoceras? sp. C. $\bullet$ E - variation of cameral depth with apical angle. Filled circles = Virgoceras sp. A, open circles $=$ Virgoceras? sp. C, diameter of circles are proportionate to the phragmocone diameter.

NMW 2012.15G.78. This is also the only specimen in which endosiphuncular deposits are visible. These are present only on the ventral side of the siphuncle, where they form very weak annuli at the septal necks combined with a thin and slightly uneven parietal lining extending adorally from the septal necks.

Remarks. - As noted above Virgoceras? sp. C differs from $V$.? sp. A in the possession of well-developed hyposeptal cameral deposits, a slightly different conch sculpture, and different trajectories when apical angle and cameral depth are plotted against each other. The outline of the siphuncle and the nature of the endosiphuncular deposits suggests some similarity with species assigned to a manuscript taxon by King (1990, pp. 169-175, pls 23-25, 27-29), but all differ in possessing wider siphuncles and more significantly, endosiphuncular deposits developed well in advance of the cameral deposits. 
Family Sactorthoceratidae Flower, 1946

Remarks. - On the evidence provided by several specimens assigned to Sactorthoceras banestanense Evans (Evans in Dastanpour et al. 2006) argued that the ontogenetic changes observed in the morphology of the siphuncle (variation in the position and degree of inflation of the siphuncle with phragmocine diameter) indicated that they belonged to the Pseudorthocerida. As noted below, the Proteoceratidae are now considered to belong within the Orthocerida, and the Sactorthoceratidae, on the basis of the siphuncle morphology seen in $S$. banestanense might be considered to be related to the Proteoceratidae, but represent forms in which the development of endosiphuncular and cameral deposits were suppressed. By contrast, Kröger et al. (2007) suggested that Murrayoceras Foerste, 1926 would form a morphological intermediate between ellesmerocerids and sactorthoceratids on the grounds of the form of the connecting ring (considered by Kröger to be relatively thick by comparison with other orthocerids), and emended the diagnosis of the family to include forms possessing endosiphuncular deposits in the form of an irregular lining or rod, combined with mural and episeptal cameral deposits. Since endosiphuncular and cameral deposits remain unknown in Sactorthoceras and the morphologically similar Braulioceras Kröger (in Kröger et al. 2007) the evidence for this relationship to ellesmerocerids relies entirely on the presence of a thicker connecting ring in these two genera. There appears to be little evidence for the presence of especially thick connecting rings in these two taxa (see Sactorthoceras gonioseptum Kobayashi 1934, pl. 18, fig. 3; S. banestanense Evans in Dastanpour et al., 2006, fig. 3a, f, m, s; Braulioceras sanjuanense Kröger et al., 2007, figs 7.2, 7.3). The taxonomic relationships of the Sactorthoceratidae may be better resolved when the extreme apical portions of Sactorthoceras or Braulioceras are known.

\section{Genus Sactorthoceras Kobayashi, 1934}

Type species. - Sactorthoceras gonioseptum Kobayashi, 1934, p. 407, from the Middle Ordovician Jigunsan Formation of the Kangweondo area, South Korea. By original designation.

\section{Sactorthoceras? sp. A}

Figures 8D, E, F, 9H

Material. - NMW 2012.15G.41 and 43. From collecting horizon F-36, unit B6 of the Shirgesht Formation, Dahaneh Kolut, Derenjal Mountains, Tabas.

Description. - Both specimens are small portions of phragmocone, each about $14 \mathrm{~mm}$ in diameter. The transverse section of NMW 2012.15G.43, which appears to be undeformed, is slightly subcircular. The apical angles of the fragments are between $5^{\circ}$ and $6^{\circ}$. In NMW 2012.15G.41 the depth of the septa is $16 \%$ of the diameter of the phragmocone. The sutures are more or less direct and transverse. Their distance apart indicates a cameral depth ranging between $16 \%$ and $23 \%$ of the phragmocone diameter. NMW 2012.15G.43 was sectioned but the septa and siphuncle were found to be broken. A fragment of septum containing the septal foramen floating in the matrix indicates that the diameter of the siphuncle at this point is about $1.1 \mathrm{~mm}$ or $8 \%$ of the diameter of the phragmocone. The septal necks (Fig. 9H) are $0.5 \mathrm{~mm}$ long and orthochoanitic in this particular fragment, but may be slightly geniculate, depending on whether the orientation of the section lies parallel to the axis of the septal foramen. There is no evidence of the presence of cameral or endosiphuncular deposits in either specimen.

Remarks. - The external form of these specimens is similar to other species assigned to Sactorthoceras in the shallow septa directly transverse sutures. General comparison of cameral depth, septal depth and siphuncle diameter with S. banestanensis and other species of Sactorthoceras (Evans in Dastanpour et al. 2006) indicates that these specimens are broadly similar to $S$. banestanensis except perhaps in the diameter of the siphuncle, which may be wider in these specimens. However, as measurement of the diameter of the siphuncle was based on a fragment of septum floating in the matrix of NMW 2012.15G.43, this is not necessarily the maximum diameter of the siphuncle. The apparent lack of endosiphuncular and cameral deposits is also consistent with an assignment to Sactorthoceras.

\section{Family Proteoceratidae Flower, 1962}

Remarks. - Following the recognition of a small, spherical or subspherical protoconch lacking a cicatrix in Isorthoceras (Kröger et al. 2009, 2011), assignment of this group to the Pseudorthocerataceae (Sweet 1964) or Pseudorthocerida (Kröger \& Isakar 2006), no longer seems tenable and the Proteoceratidae were placed in the Orthocerida (Kröger et al. 2011).

\section{Genus Gangshanoceras Zou, 1988}

Type species. - Gangshanoceras jurongense Zou (1988, pp. 321, 328, pl. 5, figs 3-6, text-figs 9, 10) from the Dawan Formation (Dapingian Stage) of Lunshan, Jurong, Jiangsu, China.

Remarks. - Gangshanoceras was described from China 

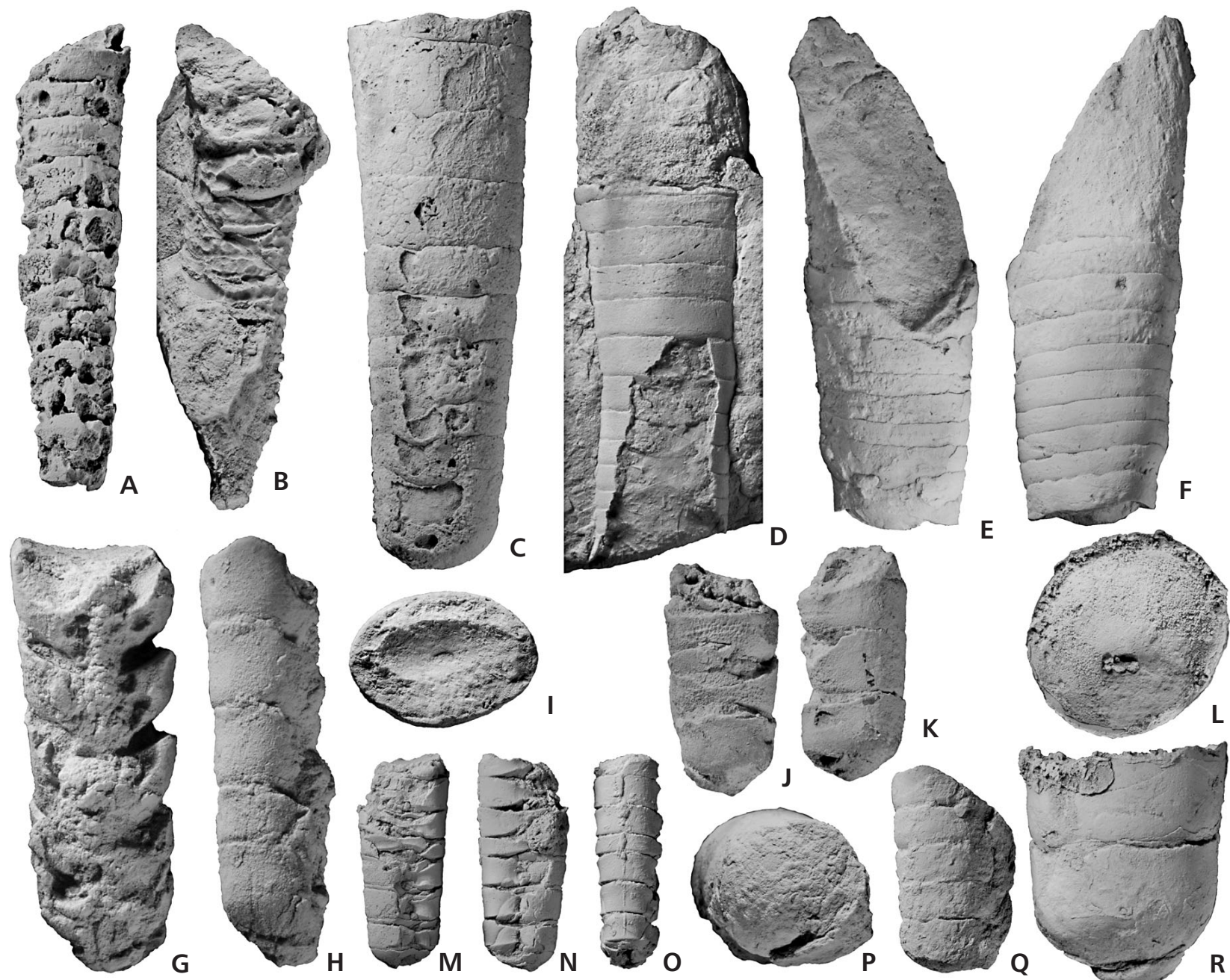

Figure 8. Cephalopods from the Shirgesht and Lashkarak formations. - A, B, M-O - Virgoceras sp. A. Shirgesht Formation. A - ventral view of phragmocone with moulds of cameral deposits; NMW 2012.15G.56; × 2.15 (see also Figs 5W, 8E, 9B, C). B - weathered phragmocone; NMW 2012.15G.64; $\times 1.37$ (see also Figs 8D, 9A, G). M-O - lateral and dorsal views of partially crushed phragmocone showing the moulds of cameral deposits and the presence of a septal furrow on the dorsal surface; NMW 2012.15G.60; × 2.2. $\bullet$ C, I - Virgoceras sp. B. Shirgesht Formation; lateral and adoral views respectively; NMW 2012.15G.11; × 1. • D-F - Sactorthoceras? sp.; Shirgesht Formation. D - portion of phragmocone showing traces of septa; NMW 2012.15G.43; × 1.25. E, F - views of partially deformed phragmocone; NMW 2012.15G.41; × 1.5. • G, H, J-L, P-R - Virgoceras sp. C. Lashkarak Formation. G, H - ventral and lateral (venter on right) views showing siphuncle and moulds of cameral deposits; NMW 2012.15G.77; $\times 2.5$. J, K - ventral and lateral (venter on left) views of a phragmocone showing moulds of finely mammilate cameral deposits on the venter; NMW 2012.15G.78; $\times 2.2$. P, Q - apical and lateral views of phragmocone; NMW 2012.15G.79; × 1.5 and $\times 1$ respectively. L, R - adoral and lateral views of part of large phragmocone; NMW 2012.15G.109; $\times 1$.

under G. jurongense and G. densum Zou from the Dawan Formation of Jiangsu, G. guichinense Ying and G. wennanense Ying, from the Zetan Formation (Dapingian Stage) of Guichi, Anhui, China. G. villicumense Kröger et al. and $G$. sp. (Kröger et al. 2007) come from the Darriwilian of the Argentine Precordillera, and as G. sp. from the Darriwilian of Öland, Sweden (King 1999). Although the Chinese species are generally similar in their weak cyrtoconic curvature and moderate rate of expansion, younger taxa may be less rapidly expanding and more strongly orthoconic in shape. This is particularly the case in Gangshanoceras sp. Kröger et al. (2007, fig. 5.10) where the siphuncle is very narrow and central in position.

\section{Gangshanoceras? sp.}

Figures 9C, 10J

Material. - A single specimen, NMW 2012.15G.72. From collecting horizon F-36, unit B6 of the Shirgesht Formation, Dahaneh Kolut, Derenjal Mountains, Tabas. This specimen is strongly recrystallised and appears partially dolomitised, so that much of the original form of the shell is obscured, and some structures including the connecting rings and the margins of cameral deposits are now diffuse and difficult to define.

Description. - This specimen consists of a portion of 

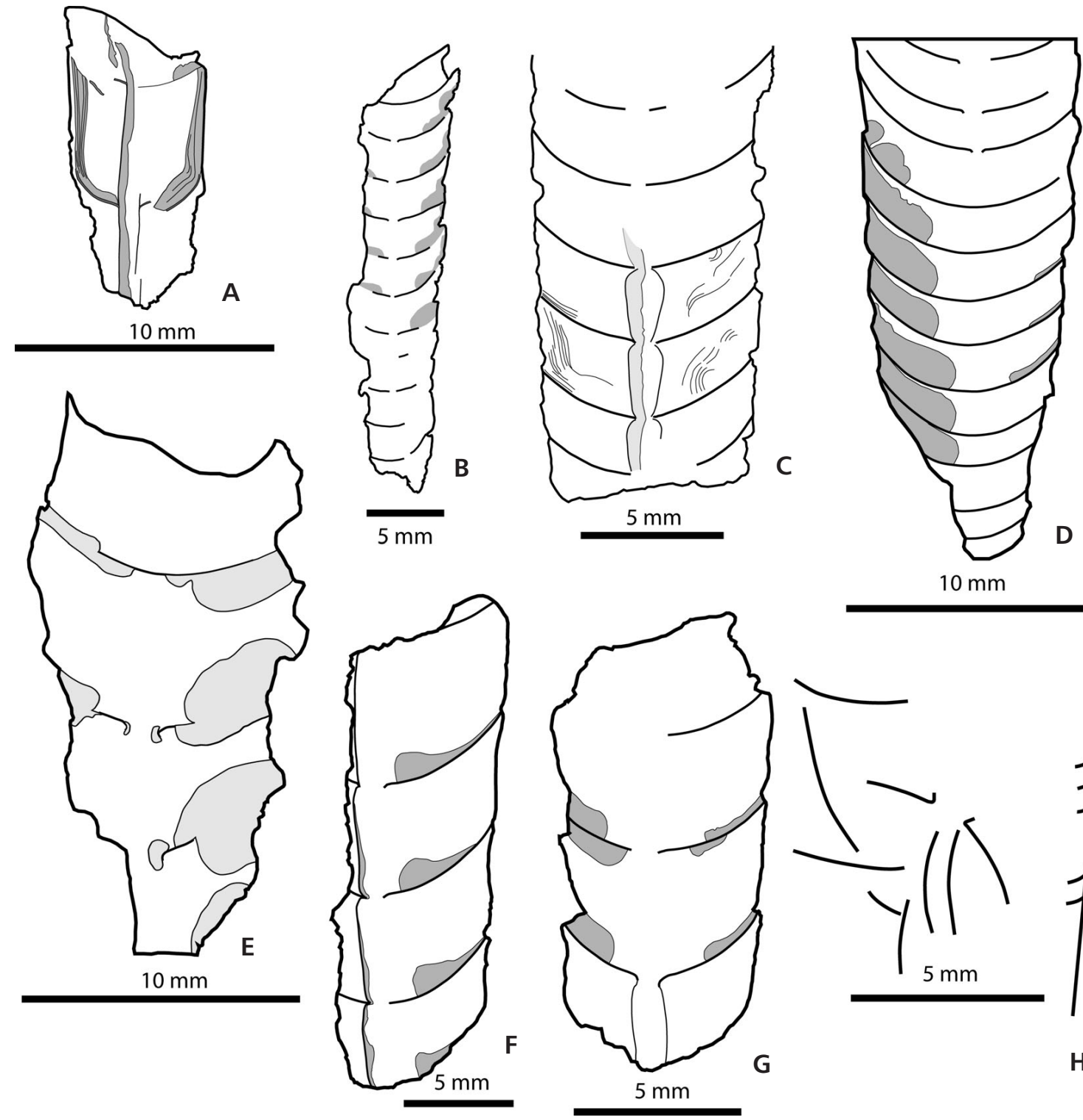

$10 \mathrm{~mm}$
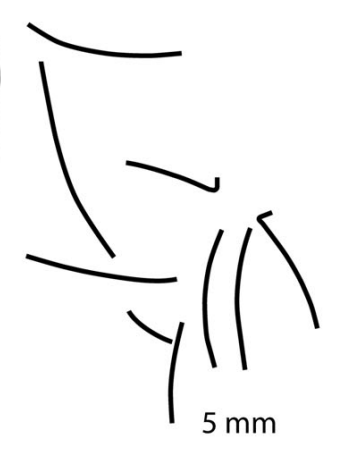

G

Figure 9. Interpretative illustrations of polished sections through cephalopod phragmocones from Shirgesht and Lashkarak formations. - A - troedssonellid gen. et sp. indet. Thin episeptal deposits and endosiphuncular lining shaded. Shirgesht Formation. NMW 2012.15G.58 (see also Fig. 5U, 10F). B, D - Virgoceras sp. A. Shirgesht Formation. B - NMW 2012.15G.56 (see also Figs 5W, 8A, 10E, L) and D - NMW $2012.15 \mathrm{G} .64$ (see also Figs 9C, 8B, 10A) respectively. Well-developed episeptal cameral deposits shaded. $\bullet \mathrm{C}-$ Gangshanoceras? sp. Episeptal cameral deposits and inflated siphuncular segments containing a parietal lining are shaded. Shirgesht Formation. NMW 2012.15G.78 (see also Fig. 9J). E - Virgoceras sp. B. Episeptal and hyposeptal cameral deposits with annulosiphonate deposits developed at the septal necks. Shirgesht Formation. NMW 2012.15G.40 (see also Figs 5X, 9B, C). • F - Virgoceras sp. C. Thin episeptal cameral deposits with parietal deposits growing adorally from the septal necks. Lashkarak Formation. NMW 2012.15G.77 (see also Figs 7G, H, 9H). • G - Virgoceras sp. C. Episeptal and hyposeptal cameral deposits and intact siphuncular segment present. Lashkarak Formation. NMW 2012.15G.78 (see also Figs 7J, K, 9I). - H - Sactorthoceras? sp.; Shirgesht Formation. Section through phragmocone showing traces of septa attached to the phragmocone walls and fragments of septa floating in the matrix, including a fragment showing the septal foramen; NMW 2012.15G.43.

phragmocone $18 \mathrm{~mm}$ long and increasing in diameter from $7.2 \mathrm{~mm}$ to $8.3 \mathrm{~mm}$ in a distance of $15 \mathrm{~mm}$, giving a rate of expansion of about $4^{\circ}$. Its cross-section is circular, and the septa are $1.1 \mathrm{~mm}$ in depth or about $16 \%$ that of the phragmocone diameter whilst being about $2.3 \mathrm{~mm}$ distant, giving a cameral depth about $33 \%$ that of the phragmocone diameter. Although the septa appear to be intact, sectioning of the specimen suggests that the siphuncle may have been displaced from segment to segment, and in many places, the connecting ring has been lost. Towards the apical end of the specimen, the septal foramen lies $44 \%$ of the way across the diameter of the phragmocone, and is about $13 \%$ that of the phragmocone in diameter. The diameter of the connecting ring reaches a maximum of $24 \%$ that of the 


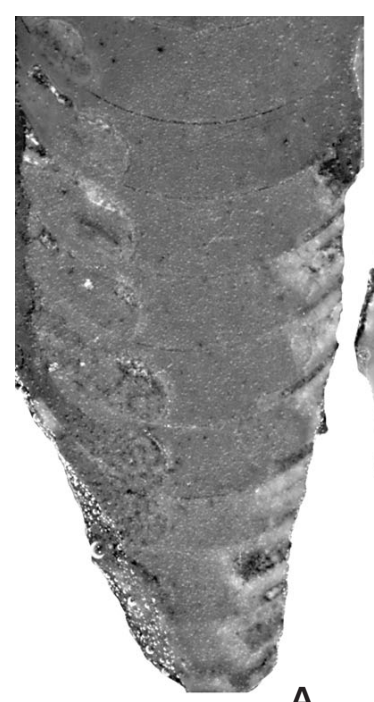

A
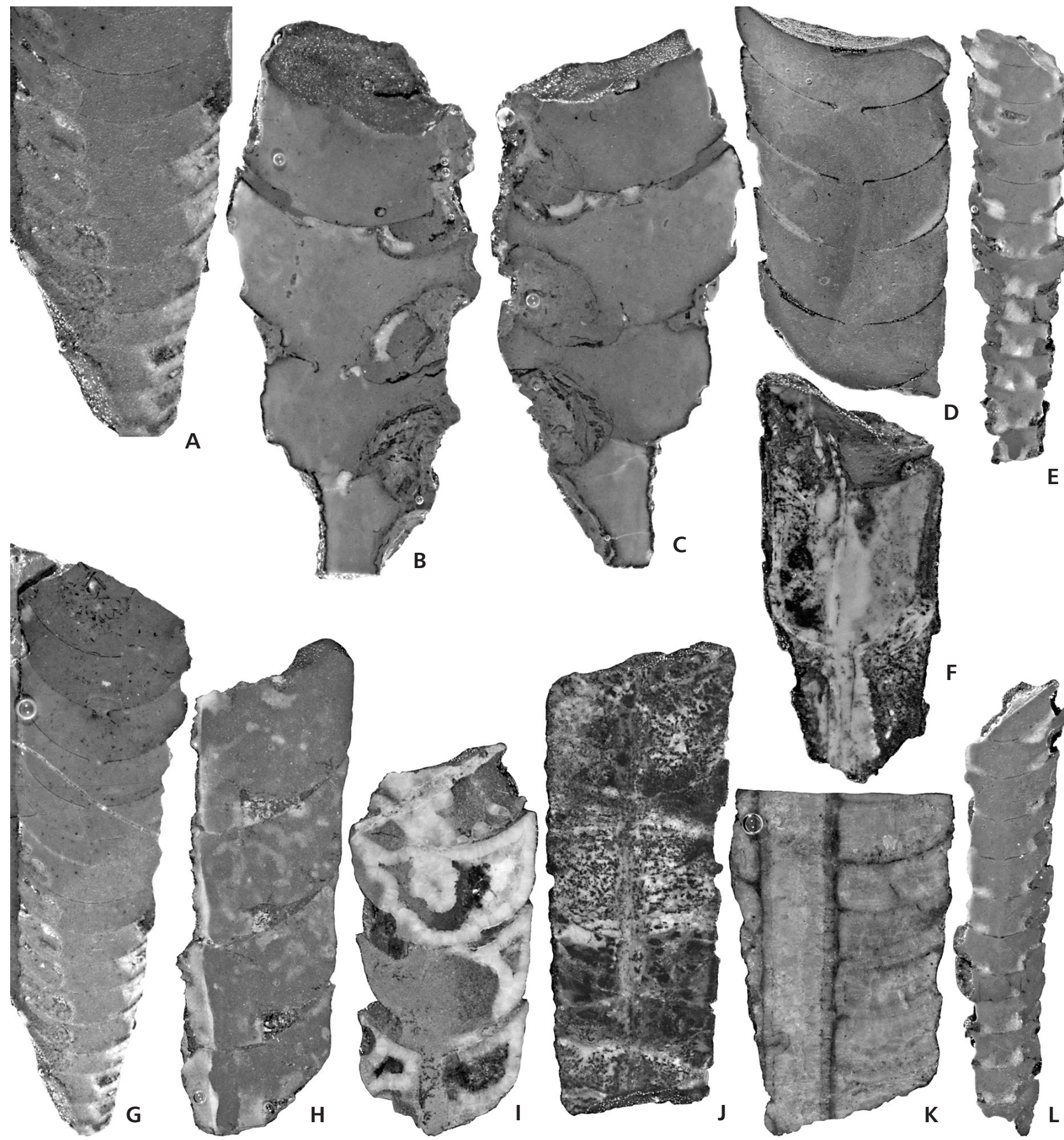

$E$

Figure 10. Polished sections through cephalopod phragmocones from Shirgesht and Lashkarak formations. • A-E, L - Virgoceras sp. A. Exhibiting well developed cameral deposits ventrally and septal necks. Shirgesht Formation. NMW 2012.15G.64; × 3.6, × 2.4 respectively (see also Figs 8B, 9C). - B, C - Virgoceras sp. B. Showing the presence of episeptal and hyposeptal cameral deposits with annulosiphonate deposits developed at the septal necks. Shirgesht Formation. NMW 2012.15G.40; both $\times 4.1$ (see also Figs 5X, 9E). D - Virgoceras sp. A. Siphuncle devoid of cameral deposits and showing orthochoanitic to suborthochoanitic septal necks. Shirgesht Formation. NMW 2012.15G.13; × 1.9 (see also Figs 3A, 5N, O). E E L - Virgoceras sp. A. With nearly achoanitic septal necks and well-developed episeptal cameral deposits. Shirgesht Formation. NMW 2012.15G.56; both $\times 2.4$ (see also Figs 5W, 8A, 9B). - F - troedssonellid gen. et sp. indet. Thin episeptal deposits and endosiphuncular lining visible. Shirgesht Formation. NMW 2012.15G.58; $\times 3.5$ (see also Figs 5U, 8A) $\bullet$ H - Virgoceras sp. C. Thin episeptal cameral deposits with parietal deposits growing adorally from the septal necks. Lashkarak Formation. NMW 2012.15G.77; × 4.2 (see also Figs 8G, H, 9F). • I - Virgoceras sp. C. With episeptal and hyposeptal cameral deposits and an intact siphuncular segment. Lashkarak Formation. NMW 2012.15G.78; × 4.3 (see also Figs 8J, K, 9G). • J - Gangshanoceras? sp. Episeptal cameral deposits, inflated siphuncular segments containing a parietal lining. Shirgesht Formation. NMW 2012.15G.72; × 4.0 (see also Fig. 8C). • K - Protocyclendoceras sp. B. Lashkarak Formation. NMW 2012.15G.89; × 3.6 (see also Fig. 5H-M). 
phragmocone at about $73 \%$ of the way adorally along the siphonal segment, giving a vase-shaped outline to each segment. Where not too strongly recrystallised the camerae are seen to be heavily invested with cameral deposits that appear to be mainly episeptal and mural, although there is an indication of the presence of minor hyposeptal deposits. Endosiphuncular deposits consist of what appears to be a parietal lining that is slightly thickened at the septal foraminae, suggesting that annulosiphonate deposits may have been present at the septal necks.

The surface of the shell appears to be smooth, but it is also strongly corroded, so that it is not possible to be certain with regard to the nature of the shell sculpture.

Remarks. - The poor preservation of this fragment makes its correct assignment uncertain, as it is so short that ontogenetic variation in the morphology cannot be demonstrated. It clearly differs from the material described above and assigned to Virgoceras both in the lower rate of expansion of the shell, the inflated connecting rings and the presence of parietal endosiphuncular deposits. By comparison with the Chinese species assigned to Gangshanoceras, this shell has a smaller apical angle and appears almost straight whilst possessing deeper camerae. It differs from G. villicumense in a similar manner, whilst approaching $G$. sp., from the Argentine Precordillera in the low rate of expansion, straightness and depth of the camerae. It differs from the later, however, in the possession of a much narrower siphuncle. Probably, this specimen is most similar to the material described by King (1999, fig. 5e, f) as Gangshanoceras sp. from the Darriwilian of Öland.

\section{Acknowledgments}

The authors thank Štěpán Manda (Czech Geological Survey) and Andrew King (Geckoella environmental consultants PVT Ltd) for their constructive reviews that have helped to improve this paper. David Evans thanks Andrew King for providing access to his unpublished $\mathrm{Ph} . \mathrm{D}$. thesis, and for much valuable discussion regarding Baltic taxa. Mansoureh Ghobadi Pour and Leonid Popov acknowledge logistical support from the National Museum of Wales. Fieldwork and research in Iran by Ghobadi Pour was supported by Golestan University.

\section{References}

Alavi, M. 1991. Tectonic map of the Middle East, scale 1:5,000,000. Geological Survey of Iran, Tehran.

Alavi-Naini, M. 1993. Paleozoic stratigraphy of Iran, 1-492. In Hushmandzadeh, A. (ed.) Treatise on the Geology of Iran 5. [in Farsi]

BABIN, C. 1966. Mollusques bivalves et cephalopods du Paléozoique Armoricain. Édude systematique essai sure la phylogénie des bivalves esquisse paleoécologique. 470 pp. Imprimerie Commercial et Administrative, Brest.

BABIN, C. \& GutiérReZ-MARCo, J.C. 1992. Intérêt paléobiogéograpique de la presence du genre Trocholites (Cephalopoda, Nautiloidea) dans le Dobrovitá (Llandeilo) inférieur d'Espagne. Neues Jahrbuch für Geologie und Paläontologie, Monatshefte 1992, 100-122.

Balashov, Z.G. 1968. Endotseratoidei ordovika, SSSR. 277 pp. Izdatelstvo Leningradskogo Universiteta, Leningrad. [in Russian]

BARRANDE, J. 1865-1877. Systême silurien du centre de la Bohême. Vol. II. Céphalopodes. Texte: 1867, part 1, 712 pp.; 1870, part 2, 263 pp.; 1874, part 3, 804 pp.; 1877, part 4, 742 pp.; 1877, part 5, 743 pp.; supplement: 1877, 297 pp.; 1865, pls 1-107; 1866, pls 108-244; 1868, pls 245-350; 1868, pls 351-460; 1870, pls 351-460; 1877, pls 461-544. Privately published, Prague \& Paris.

Berberian, M. \& King, G.C.P. 1981. Towards a Paleogeography and Tectonic Evolution of Iran. Canadian Journal of Earth Science 18, 210-265. DOI 10.1139/e81-019

BERgERON, J. 1894 (1893). Notes paléontologiques I. Crustacés. Bulletin de la Société géologique de France 21, 333-346.

Bruton, D.L., Wright, A.J. \& Hamedi, M.A. 2004. Ordovician trilobites from Iran. Palaeontographica, Abteilung A 271, 111-149.

Chen, T. 1984. The Ordovician cephalopod fauna and the subdivision of the Ordovician of southern Xizang (Tibet). Acta Palaeontologica Sinica 23, 452-468. [in Chinese, English abstract]

Cichowolski, M. \& VACCARI, N.E. 2011. The oldest record of Eothinoceratidae (Ellesmerocerida, Nautiloidea): middle Tremadocian of the Cordillera Oriental, NW Argentina. Geological Journal 46, 42-51. DOI 10.1002/gj.1250

Dastanpoor, M., Evans, D.H. \& Bassett, M.G. 2006. A new orthoceratoid cephalopod from the Ordovician (Caradoc) of east-central Iran. Geobios 39, 337-345.

DOI 10.1016/j.geobios.2004.11.008

Evans, D.H. 2000. A cephalopod fauna from the Ordovician of Saudi Arabia. Palaeontology 43, 573-589. DOI 10.1111/j.0031-0239.2000.00141.x

Evans, D.H. 2005. The Lower and Middle Ordovician cephalopod faunas of England and Wales. Monograph of the Palaeontographical Society, London 158(623), 1-81.

Fischer, A.G. \& Teichert, C. 1969. Cameral deposits in cephalopod shells. Unoversity of Kansas Paleontological Contributions 37, 1-30.

Flower, R.H. 1939. Study of the Pseudorthoceratidae. Palaeontographica Americana 2, 1-214.

Flower, R.H. 1946. Ordovician cephalopods of the Cincinnati region. Bulletin of American Paleontology 29, 1-656.

FLower, R.H. 1962. Notes on the Michelinoceratida. New Mexico Bureau of Mines and Mineral Resources, Memoir 10, 21-55.

Flower, R.H. \& Kummel, B. 1950. A classification of the Nautiloidea. Journal of Paleontology 24, 604-616.

Foerste, A.F. 1926. Actinosiphonate, trochoceroid, and other cephalopods. Denison University Bulletin, Journal Science Laboratories 21, 285-384.

Foord, A.H. 1887. On Endoceras duplex Wahl., with descriptions of three new species of Endoceras from the Ordovician 
of Sweden and Russia contained in the British Museum. Annals and Magazine of Natural History 5(20), 393-409. DOI 10.1080/00222938709460083

ForTEY, R.A. \& Cocks, L.R.M. 2003. Palaeontological evidence bearing on global Ordovician-Silurian continental reconstructions. Earth Science Reviews 61, 245-307.

DOI 10.1016/S0012-8252(02)00115-0

Gabbot, S.E., Siveter, D.J., Aldridge, R.J. \& Theron, J.N. 2003. The earliest myodocopes: Ostracodes from the late Ordovician Soom Shale Lagerstäte of South America. Lethaia $36,151-160$.

Gansser, A. \& Huber, H. 1962. Geological observations in the Central Elburz, Iran. Schweizerische Mineralogische und Petrographische Mitteilungen 42, 593-630.

GHAVIDEL-SYooki, M. 2006. Palynostratigraphy and palaeogeography of the Cambro-Ordovician strata in southwest of Shahrud city (Kuh-e Kharbash, near Deh-Molla), Central Alborz, Northern Iran. Review of Palaeobotany and Palynology 139, 81-95. DOI 10.1016/j.revpalbo.2005.07.006

Ghobadi Pour, M. 2006. Early Ordovician (Tremadocian) trilobites from Simeh-Kuh, Eastern Alborz, Iran, 93-118. In BASSETt, M.G. \& DeISLER, V.K. (eds) Studies in Palaeozoic palaeontology, National Museum of Wales Geological Series 25.

Ghobadi Pour, M., Kebriaee-Zadeh, M.-R. \& Popov, L.E. 2011a. Early Ordovician (Tremadocian) brachiopods from Eastern Alborz Mountains, Iran. Estonian Journal of Earth Sciences 60, 65-82. DOI 10.3176/earth.2011.2.01

Ghobadi Pour, M., Mohibullah, M., Williams, M., Popov, L.E. \& Tolmacheva, T.Y. 2011b. New early ostracods from the Ordovician (Tremadocian) of Iran: systematic, biogeographical and palaeoecological significance. Alcheringa 35, 517-529. DOI 10.1080/03115518.2011.538909

Ghobadi Pour, M. \& Popov, L.E. 2009. Fist report on the occurrence of Neseuretinus and Ovalocephalus trilobites in the Middle Ordovician of Iran. Acta Palaeontologica Polonica 54, 125-133. DOI 10.4202/app.2009.0113

Ghobadi Pour, M., Popov, L.E., Kebriaee-Zadeh, M.R. \& BAARS, C. 2011. Middle Ordovician (Darriwilian) brachiopods associated with the Neseuretus biofacies from Eastern Alborz Mountains, Iran. Memoirs of the Australasian Association of Palaeontologists 42, 263-283.

Ghobadi Pour, M. \& Turvey, S.T. 2009. Revision of some Lower to Middle Ordovician leiostegiid trilobites from Iran and China. Memoirs of the Australian Association of Australasian Palaeontologists 37, 463-480.

Ghobadi Pour, M., Vidal, M. \& Hosseini-NeZhad, M. 2007b. An Early Ordovician Trilobite assemblage from the Lashkarak Formation, Damghan area, northern Iran. Geobios 40, 489-500. DOI 10.1016/j.geobios.2005.04.007

Ghobadi Pour, M., Williams, M. \& Popov, L. 2007a. A new Middle Ordovician arthropod fauna (Trilobita, Ostracoda, Bradoriida) from the Lashkarak Formation, Eastern Alborz Mountains, northern Iran. GFF 129, 245-254.

DOI 10.1080/11035890701293245

Ghobadi Pour, M., Williams, M., Vannier, J., Meidla, T. \& Popov, L.E. 2006. Ordovician ostracods from east-central Iran. Acta Palaeontologica Polonica 51, 551-560.

Glaus, M. 1965. Die Geologie des Gebietes nördlich des Kandevan-Passes (Zentral Elburz), Iran. (Diss.) Mitteilungen aus dem Geologischen Institut der Eidgenössischen, Technische Hochschule und Universität Zürich, N.S. 48, 1-165.

GLENISTER, B.F. 1952. Ordovician nautiloids from New South Wales. Australian Journal of Science 15, 89-91.

Gregoire, C. \& Teichert, C. 1965. Conchiolin membranes in shell and cameral deposits of Pennsylvanian cephalopods, Oklahoma. Oklahoma Geology Notes 25, 175-201.

Hairapetian, V., Ghobadi Pour, M., Popov, L.E. \& ModzaLEVSKAYA, T.L. 2012. Stegocornu and associated brachiopods from the Silurian (Llandovery) of Central Iran. Estonian Journal of Earth Sciences 61, 82-104.

DOI 10.3176/earth.2012.2.02

Holm, G. 1898. Palaeontologiska notiser II: Om ett par Bactrites-liknade Untersiluriska Orthocera-former. Geologiska Föreningens I Stockhom Förhandlingar 20, 354-360.

Hook, S.C. \& Flower, R.H. 1977. Late Canadian (Zones J, K) cephalopod faunas from southwestern United States. New Mexico Bureau of Mines and Mineral Resources, Memoir 10, $1-102$.

Hyatт, A. 1883-84. Genera of fossil cephalopods. Boston Society of Natural History, Proceedings 22, 253-338. [December 1883, pp. 253-272; January 1884, pp. 273-338]

KalantaRI, A. 1981. Iranian fossils. Geological Laboratories Publication 9. 216 pp. Ministry of Oil, National Iranian Oil Company, Tehran.

KING, A.H. 1990. Lower and Middle Ordovician Cephalopoda of Baltoscandia. Unpublished Ph.D. thesis, University of Wales, Swansea.

King, A.H. 1999. A review of Volkhovian and Kundan (ArenigLlanvirn) nautiloids from Sweden, 137-159. In OLÓRIZ, F. \& RodrigueZ-Tovar, F.J. (eds) Advancing research on living and fossil cephalopods. i-xvi + $550 \mathrm{pp}$. Kluwer Academic / Plenum Publishers, New York.

Kobayashi, T. 1934. The Cambro-Ordovician formations and faunas of South Chosen. Palaeontology. Part I. Middle Ordovician faunas. Journal of the Faculty of Sciences, Imperial University of Tokyo, Section 2(3), 329-519.

Kobayashi, T. 1935. Restudy of Machuroceras with a brief note on the classification of Endoceroids. Journal of the Geological Society of Japan 42, 436-452.

DOI 10.5575/geosoc. 42.736

KRÖGER, B. 2004. Revision of Middle Ordovician orthoceratacean Nautiloids from Baltoscandia. Acta Palaeontologica Polonica 49, 57-74.

KRÖGER, B., BERESI, M.S. \& LANDING, E. 2007. Early orthoceratoid cephalopods from the Argentine Precordillera (Lower - Middle Ordovician). Journal of Paleontology 81, 1263-1280.

KröGER, B., EbBestad, J.O.R., HÖGSTRÖM, A.E.S. \& FrISK, Å.M. 2011. Mass concentrations of Hirnatian cephalopods from the Siljan District, Sweden: taxonomy, palaeoecology and palaeobiogeographic relationships. Fossil Record 14, 35-53.

DOI 10.1002/mmng.201000014

KRÖGER, B. \& Evans, D.H. 2011. Review and palaeoecological analysis of the late Tremadocian - early Floian (Early Ordovician) cephalopod fauna of the Montagne Noire, France. Fossil Record 14, 5-34. DOI 10.1002/mmng.201000013

KRÖGER, B. \& ISAKAR, M. 2006. Revision of annulated orthoceridian cephalopods of the Baltoscandian Ordovician. Fossil Record 9, 137-163. DOI 10.1002/mmng.200600005 
Kröger, B. \& Lefebvre, B. 2012. Palaeogeography and palaeoecology of early Floian (Early Ordovician) cephalopods from the Upper Fezouata Formation, Anti-Atlas, Morocco. Fossil Record. DOI 10.1002/mmng.201200004

KröGer, B., Zhang, Y. \& IsAKar, M. 2009. Discosorids and oncocerids (Cephalopoda) of the Middle Ordovician Kunda and Aseri stages of Baltoscandia and the early evolution of these groups. Geobios 42, 273-292.

DOI 10.1016/j.geobios.2008.09.006

Kunn, O. 1940. Paläozoologie in Tabellen. 50 pp. G. Fischer, Jena.

Lindenberg, H.G., Gröler, K., Jacobshagen, V. \& IbbeKen, H. 1984. Post-Paleozoic stratigraphy, structure and orogenetic evolution of the southern Sabzevar zone and the Taknar block. Neues Jahrbuch für Geologie und Paläontologie, Abhhandlungen 168, 287-326.

Marek, J. 1999. Ordovician cephalopods of the Prague Basin (Barrandian area, Czech Republic): a review. Acta Universitatis Carolinae, Geologica 43, 413-416.

MANDA, S̆. 2008. Trocholites Conrad, 1838 (Nautiloidea, Tarphycerida) in the Middle Ordovician of the Prague Basin and its palaeobiogeographical significance. Bulletin of Geosciences 83, 327-334. DOI 10.3140/bull.geosci.2008.03.327

Mutvei, H. 2002. Connecting ring structure and its significance for classification of the orthoceratid cephalopods. Acta Palaeontologica Polonica 47, 157-168.

Pillet, J. 1973. Sur quelques trilobites ordoviciens d'Iran oriental. Annales de la Société Géologique du Nord 93, 33-38.

Popov, L.E., Ghobadi Pour, M., BASSETt, M.G. \& KebriaEe-Zadeh, M.R. 2009. Billingsellide and orthide brachiopods: New insights into earliest Ordovician evolution and biogeography from Northern Iran. Palaeontology 52, 35-52. DOI 10.1111/j.1475-4983.2008.00833.x

Popov, L.E., Ghobadi Pour, M. \& Hosseini, M. 2008. Early to Middle Ordovician lingulate brachiopods from the Lashkarak Formation, Eastern Alborz Mountains, Iran. Alcheringa 32, 1-35. DOI 10.1080/03115510701757126

RAMEZANI, J. \& TuCKER, R.D. 2003. The Saghand region, central Iran: U-Pb geochronology, petrogenesis and implications for Gondwana tectonics. American Journal of Science 303, 622-665. DOI 10.2475/ajs.303.7.622

Ruttner, A., Nabavi, M.H. \& Hajian, J. 1968. Geology of the Shirgesht area (Tabas area, East Iran). Geological Survey of Iran Report No. 4, 1-133.

SÁ, A.A. \& GutiérReZ-MArCo, J.C. 2009. Cefalópodos del Ordovícico de la Formación Valongo, norte de Portugal. Geogaceta 47, 9-12.

REED, F.R.C. 1906. The Lower Palaeozoic fossils of the Northern Shan States, Burma. Memoirs of the Geological Survey of India, Palaeontologia Indica, New Series 2(3), 1-154.

SAlter, J.W. 1849. Orthoceras vagans Salter, MSS, 153. In Sharpe, D. (ed.) On the geology of the neighbourhood of Oporto, including the Silurian coal and slates of Vallongo. Quarterly Journal of the Geological Society of London 5.

Schlotнeim, E.F. von 1820. Die Petrefactenkunde auf ihrem jetzigen Strandpunkte durch die Beschreibung seiner Sammlung versteinerter und fossiler Überreste des Theirund Pflanzenreichs der Vorwelt erläutert. 1xii +437 pp. Gotha.
SeIlacher, A. 1969. Sedimentationsprozesse in Ammoniten. Akademie der Wissenschaften und der Literatur, Mainz 9, 191-203.

Stöcklin, J. \& Setudehnia, A. 1991. Stratigraphic lexicon of Iran. Geological Survey of Iran Report 18, 1-376.

SweEt, W.C. 1964. Orthocerida, 216-261. In Moore, R.C. (ed.) Treatise on invertebrate paleontology. Part K. Mollusca 3, Cephalopoda. General features, Endoceratoidea, Actinoceratoidea, Nautiloidea, Bactritoidea. xxxvii +519 pp. Geological Society of America \& University of Kansas Press, Boulder \& Lawrence.

Teichert, C. 1933. Der Bau der actinoceroiden cephalopoden. Palaeontographica, Abteilung A 78, 111-230.

Teichert, C. \& Glenister, B.F. 1952. Fossil nautiloid faunas from Australia. Journal of Paleontology 26, 730-752.

Teichert, C. \& Glenister, B.F. 1954. Early Ordovician cephalopod fauna from Northwestern Australia. Bulletins of American Paleontology 35, 153-258.

Torsvik, T.H. \& Cocks, L.R.M. 2009. The Lower Palaeozoic palaeogeographical evolution of the northeastern and eastern peri-Gondwanan margin from Turkey to New Zealand, 3-22. In BassetT, M.G. (ed.) Early Palaeozoic Peri-Gondwana Terranes: New Insights from Tectonics and Biogeography. Geological Society of London, Special Publication 325.

VANNIER, J.M.C. 1986. Ostracodes Binodicopa de l'Ordovicien (Arenig-Caradoc) Ibero-Armoricain. Palaeontographica, Abteilung A 193, 77-143.

VanNiER, J.M.C., AbE, K. \& IKUTA, K. 1998. Feeding in myodocopid ostracods: functional morphology and laboratory observations from videos. Marine Biology 3, 391-408. DOI $10.1007 / \mathrm{s} 002270050406$

Weitschat, W. 1983. Ostracoden (O. Myodocopida) mir Weichkörper-Erhaltung aus der Unter-Triass von. Spitzbergen. Paläontologische Zeitschrift 57, 309-333.

Xiao, C., Chen, Z., Liu, L. \& He, Y. 2006. Ordovician cephalopod biofacies of South China and its provincialization. Journal of China University of Geosciences 17, 221-230. DOI 10.1016/S1002-0705(06)60031-9

Yabe, H. \& Hayasaka, I. 1920. Palaeontology of South China. Geographical research in China, 1911-1916. Report 3. 221 pp. Geographical Society, Tokyo.

ZiTTEL, K.A. VON 1900. Text-book of paleontology. Vol. I. 706 pp. Macmillan, London \& New York.

Zhang, T.R. 1981. Trilobita, 134-213. In XI'An Institute of GEology and Mineral Resources (ed.) Palaeontological atlas of Northwest China, Xinjiang, Vol. 1. Geological Publishing House, Beijing. [in Chinese]

Zhuravleva, F.A. 1959. O semeistve Michelinoceratida. Materialy $k$ Osnovam Paleontologii 3, 47-48.

Zhuravleva, F.A. 1964. New Ordovician and Silurian cephalopods from the Siberian platform. Paleontological Journal 1964(1), 87-100.

Zhuravleva, F.A. 1994. The order Dissidocerida (Cephalopoda). Paleontological Journal 28, 115-133.

Zhou, Z.Y. \& DeAN, W.T. 1986. Ordovician trilobites from Chedao, Gansu Province, north-west China. Palaeontology 29, 743-786.

Zou, X.P. 1988. Ordovician cephalopod fauna from Lunshan, Jurong, Jiangsu. Acta Palaeontologica Sinica 27, 309-330. [in Chinese, English abstract] 